\title{
Upper Cretaceous Radiolarian Assemblages and Paleoenvironments of the Sverdrup Basin, Ellef Ringnes Island, Nunavut, Canada
}

\author{
by
}

Adam Thomas Pugh

A thesis submitted to the Faculty of Graduate and Postdoctoral Affairs in partial fulfillment of the requirements for the degree of

Master of Science

in

Earth Sciences

Carleton University

Ottawa, Ontario

(C) 2012, Adam Thomas Pugh 


\section{Abstract}

A late Albian to Campanian sedimentary record on Ellef Ringnes Island, Canadian Arctic Archipelago, records variable paleoenvironmental conditions within the Cretaceous Boreal Sea and Sverdrup Basin. The upper Albian to lower Cenomanian uppermost Christopher and Hassel formations represent a regressive system tract from offshore to shoreface/terrestrial paleoenvironments. The upper Cenomanian to Campanian shales of the Kanguk Formation signify a distal central basin setting controlled by increased subsidence and high global sea levels. Siliceous pelagic faunas and floras dominate the basin and herein, a new radiolarian zonation for the Boreal Sea is proposed. Alternating diversity and abundance patterns are interpreted as a response to sea-level controlled productivity systems. Transgressive phases correspond to low diversity shallow dwelling radiolarian taxa with an expanded Oxygen Minimum Zone (OMZ); regressive and lowstand phases are coupled with radiolarian radiations of deeper dwelling species and a depressed OMZ. The late Cenomanian to Coniacian is marked by increased preservation of marine-type organic matter, whereas the terrestrial influence is prevalent during the late Coniacian to Campanian. Benthic environments are dominated by anoxic conditions, as suggested by the lack of benthic fauna. Only the Santonian records a return to dysoxic benthic conditions. Radiolarian faunal comparisons to more southern localities suggest migration routes from the east through narrow North Atlantic pathways and from the Pacific through the Alaskan-Asian Pathway. 


\section{Acknowledgements}

I would like to acknowledge and thank, first and foremost, my supervisor Dr.

Claudia Schröder-Adams for having provided me the opportunity to pursue two incredible field seasons in the Canadian Arctic, and the experience of both Polar extremes. Her guidance, support, wisdom, and ambition are all most appreciated, and inspiring. Her willingness to give her time generously, and her enthusiasm, allowed for compelling scientific discourse and conversation, and made for incredible scientific inquiry from a bleak and practically miserable sampling season. I would also like to extend appreciation to Dr. Jennifer Galloway for providing Rock Eval and geochemistry data, and for her encouragement, support and friendship through the duration of this thesis, and in the field and to Dr. Jens Herrle, for his insights into the isotopic research of this section, and motivating dialogue and enthusiasm during fieldwork.

I would also like to thank Dr. Elizabeth Carter for her help and guidance with respect to Radiolarian research and naming. Her support was invaluable to this study, together with her consistent and expeditious counsel and suggestions. I would further like to recognize and appreciate Dr. James Haggart for his valuable assistance with regard to macrofossil identification. Further thanks to Jianqun Wang for his technical assistance and expertise with the SEM at Carleton University.

Financial support to Dr. Schröder-Adams was provided by the National Science and Engineering Research Council, together with the Geological Survey of Canada and the Geomapping for Energy and Minerals program and ConocoPhillips Houston and Calgary. Together with the logistical support and services of the Polar Continental Shelf Project and their service staff, two incredible and productive seasons were spent on Ellef 
Ringnes and Axel Heiberg Islands. I also would like to thank ConocoPhillips Calgary to provide me with a highly productive internship that took place throughout my studies. Dr. Ashton Embry is thanked for sharing his extensive knowledge about Arctic geology with me and Drs. Keith Dewing and Steve Grasby are thanked for logistical support during the Ellef Ringnes field season.

To my friends, and fellow graduate students, thank you for your supportive comradery, outlets for frustration, and for always providing wise guidance. Through these past two years, I have had and have found, indelible memories and incredible peers. Finally to my parents. I could never have predicted that I would be in this field of study, nor where I am today, but you were always there to support me and guide me through all of the toughest choices, and I will forever be indebted to you both. 


\section{Table of Contents}

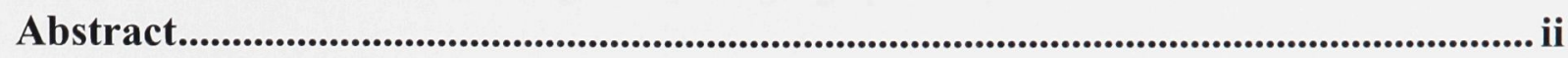

Acknowledgements …..................................................................................................ii

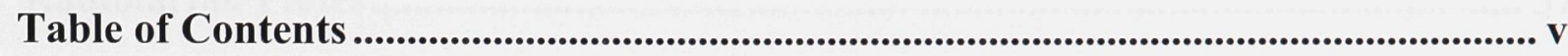

List of Tables ................................................................................................................ vii

List of Figures................................................................................................................. viii

1 Chapter: Introduction ..................................................................................... 1

2 Chapter: Study Area and Geological Setting ................................................................ 3

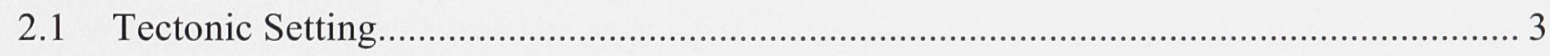

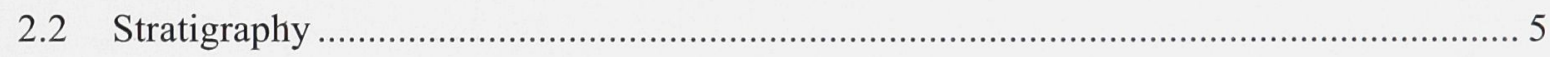

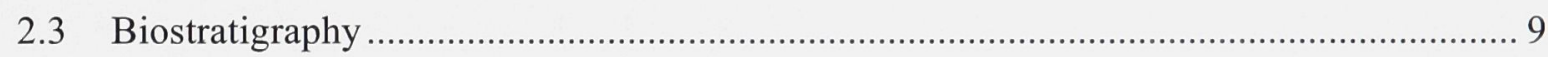

3 Chapter: Methods ......................................................................................................... 11

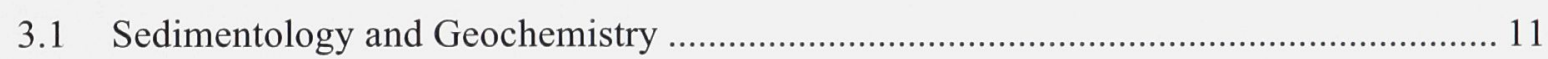

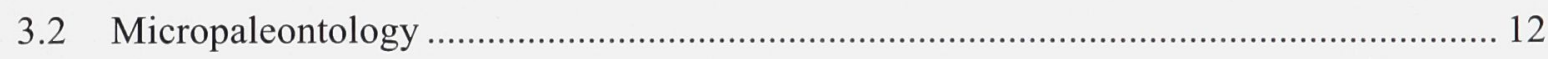

4 Chapter: Results........................................................................................................ 15

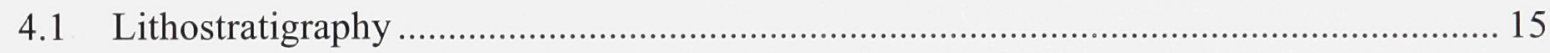

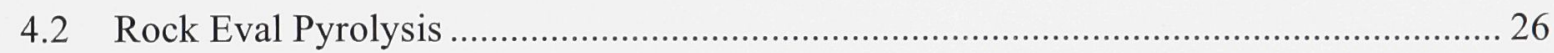

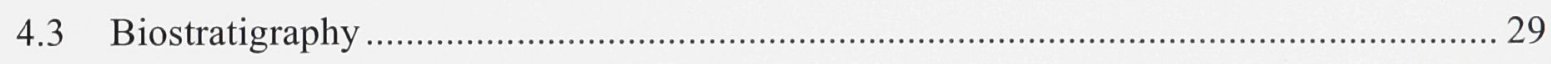

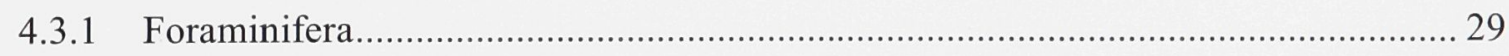

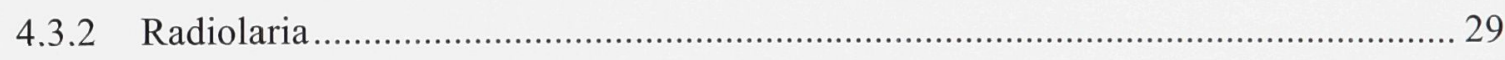

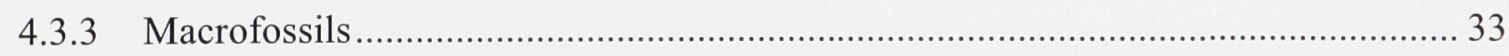

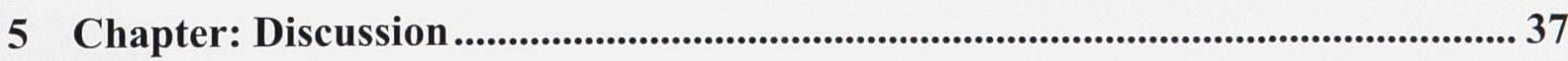

5.1 Stage Boundaries and Radiolarian Biostratigraphy in the Boreal Sea ............................ 37

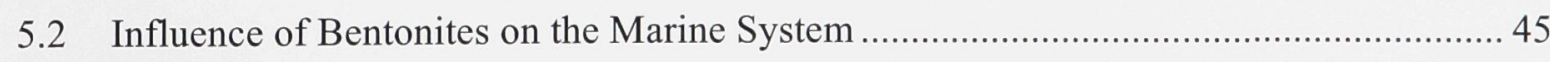


5.3 Sequence Stratigraphy of the late Cretaceous from Hoodoo Dome: Integration with the

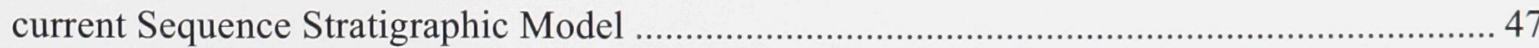

5.4 Paleoenvironmental change and paleogeographic implications in the Boreal Sea .......... 50

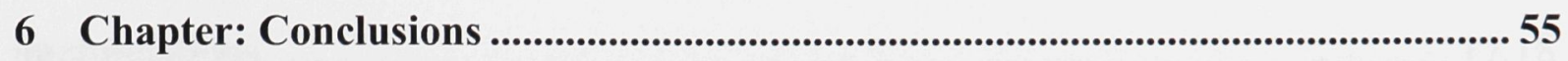

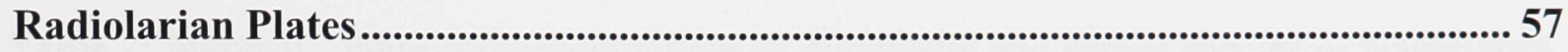

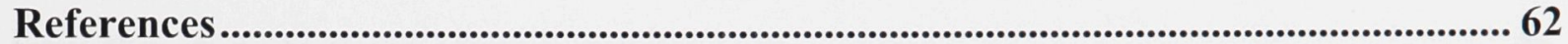




\section{List of Tables}

Table 1: Facies of the Hassel and Kanguk formations with descriptions and interpretations. 17,18

Table 2: Summary table comparing ranges of diagnostic and robust species of Nassellaria from this study to those of other authors. 45 


\section{List of Figures}

Figure 1: Outline of the Sverdrup Basin of the Canadian Arctic Archipelago. Red Lines outline the extent of the basin. Stippled island is Ellef Ringnes Island, with study locality indicated by the black dot. Modified after Embry and Beauchamp (2008)....................... 3 Figure 2: Geologic map of Hoodoo Dome on Ellef Ringnes Island, redrafted from Stott (1969). Inset shows location of Hoodoo Dome relative to the Canadian Arctic Archipelago, star marks study locality

Figure 3: Lithostratigraphic correlation chart illustrating the lateral variation in units and sequences. The section studied here (marked with the red line) is the measured section located near basin center on Ellef Ringnes Island. After Embry \& Dixon (1992). 8

Figure 4: Uppermost Christopher and Hassel formations detailed measured section showing formations, facies, and lithology.

Figure 5: Kanguk Formation detailed measured section showing formations, facies, and lithology 25

Figure 6: Simplified lithological log of the measured section at Hoodoo Dome compared to changes in Total Organic Carbon (TOC) and Hydrogen Index..... 27

Figure 7: Pseudo van Krevelen diagrams for the Hassel and Kanguk formations from Hoodoo Dome. 28

Figure 8: Radiolarian taxonomic range chart 34

Figure 9: Correlation chart of radiolarian zones from California, the North Atlantic Ocean, the Moscow Basin and the zonation proposed from this study in the Sverdrup Basin. 
Figure 10: Compilation of Kanguk Formation analysis showing clastic input proxies $\% \mathrm{Al}, \mathrm{Ti} / \mathrm{Al}, \mathrm{Mo}$ and $\% \mathrm{~S}$, Total Organic Carbon, Hydrogen Index, percent ratio of Spumellarian:Nassellarian content, radiolarian preservation and abundance curves. Radiolarian and notable events and OAE's are superimposed.

Figure 11: Compilation of stratigraphy from the Kanguk Formation, Atlantic sea level curve from Kominz et al. (2008) and estimate from this study, OAE signals, Rock Eval and radiolarian data. .38

Figure 12: Paleogeographic reconstruction for the Santonian ( $85 \mathrm{Ma}$ ) by Blakey (2011) showing possible migratory routes and gateways with respect to the locations of other study areas, as noted within the text 


\section{Chapter: Introduction}

During the Cretaceous Period, the climate-ocean system was in flux, due to increases in the rates of tectonism, global surface and deep-water temperature changes, atmospheric and oceanic $\mathrm{CO}_{2}$ concentrations, and Oceanic Anoxic Events (OAE's) (e.g. Leckie et al., 2002; Price, 1999; Friedrich et al., 2012). Further, it is debated that the Polar Regions experienced ice-free summers during the Cretaceous, consequentially increasing sea levels and flooding interior basins (Price, 1999; Barron et al., 1982; Huber et al., 2000). Resulting large variations in sea level caused significant paleogeographic changes (e.g. Ziegler \& Rowley, 1998).

The study locality at Hoodoo Dome (figs. 1, 2), an anhydrite diapir, is nearly centered within the Sverdrup Basin on Ellef Ringnes Island (fig.1). Exposing much of the late Cretaceous stratigraphy within the basin, with most topography within the central Sverdrup Basin coinciding with Mesozoic compressional tectonics and diapir emplacement (Boutelier et al., 2010). This locality provides exposure of the late Cretaceous Christopher, Hassel and Kanguk formations, their genetic relationships and their contacts. Moderately dipping bedding, minor topography and recent erosion along rivers allow for characterizing, describing and sampling the formations along a measured section. Future dating of bentonites preserved within the sequence will further assist in determining the timing of deposition.

This study addresses the uppermost Albian to Campanian sedimentary record of the Boreal Sea as exposed on Ellef Ringnes Island and concentrates on radiolarian assemblages that appear abundantly within the Kanguk Formation. Micropaleontological studies throughout the Boreal realm are sparse and limited stratigraphic resolution has to 
this date not permitted subdivision of the Kanguk Formation although it encompasses nearly the entire upper Cretaceous. Radiolarians, siliceous zooplankton, make valuable index fossils including ornate species and robust tests, although some taxa are biostratigraphically long ranging (De Wever et al., 2001; Pessagno, 1976). Within Canada, especially within the Cretaceous, very few studies have attempted their use as pelagic biostratigraphic index fossils. References to the presence of radiolaria throughout the Sverdrup Basin and the Western Interior Sea have been noted for many years (e.g. Wall, 1975, 1983; Sliter, 1981; Stelck et al., 2007; Haggart et al., in press). Due to their generally poor preservation, these studies note their presence but lack thorough descriptions and ranges, however, there have been a few studies that have described the most dominant and robust species (e.g. Wall, 1983). Through the study of Albian through Campanian strata from the Sverdrup Basin and the description of the radiolarian fauna, paleoceanographic and paleoenvironmental reconstructions of the Canadian Boreal Sea can be refined. A preliminary radiolarian zonation for the Cenomanian through Campanian is proposed and correlated with other microfossil and macrofossil occurrences, global sea-level trends and geochemical data. These correlations and new biostratigraphic data improve our understanding of the complex Albian-Campanian paleoenvironmental history of the Sverdrup Basin, and the Boreal Realm as a whole. 


\section{Chapter: Study Area and Geological Setting}

\subsection{Tectonic Setting}

The Sverdrup Basin is a Permo-Carboniferous pericratonic basin consisting of 13 $\mathrm{km}$ of Carboniferous to Eocene strata. The basin was created through rifting of the

Siluro-Devonian Ellesmerian Orogenic Belt (Balkwill, 1978; Trettin, 1991; Embry \& Beauchamp, 2008).

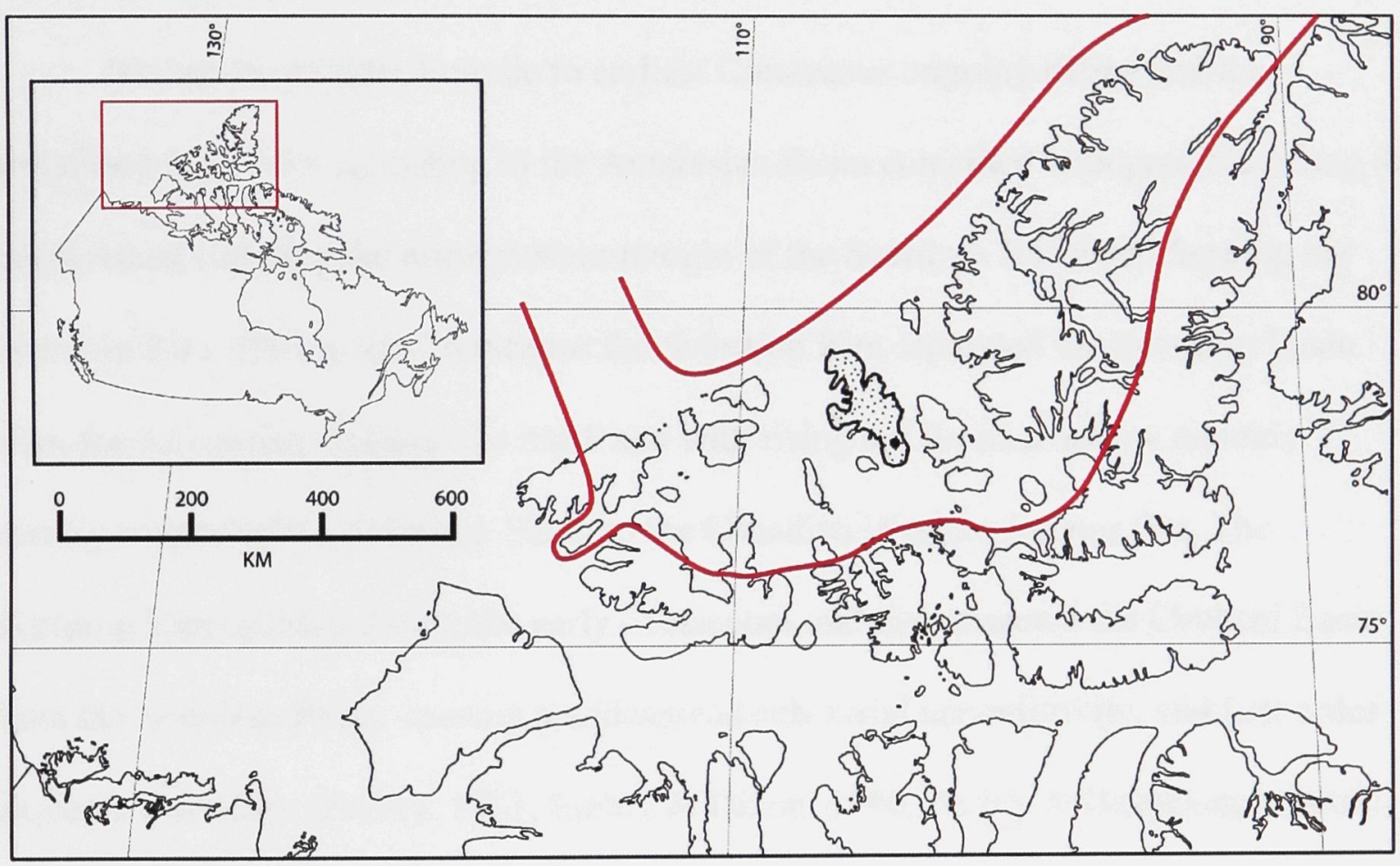

Figure 1: Outline of the Sverdrup Basin of the Canadian Arctic Archipelago. Red Lines outline the extent of the basin. Red box in inset shows location of basin with respect to Canada. Stippled island is Ellef Ringnes Island, with study locality indicated by the black dot. Modified after Embry and Beauchamp (2008).

At the onset of the Mesozoic the Sverdrup Basin had a bathymetric relief of an estimated $2 \mathrm{~km}$ or more following post-rift crustal subsidence. The depositional setting of the Sverdrup Basin shifted from being a carbonate shallow shelf setting during the 
Carboniferous and Permian to a siliciclastic-dominated basin in the Triassic, where flooding of the basin's margins allowed for deltaic progradation and further sediment influx (Embry \& Beauchamp, 2008; Embry, 1988, 1991). Furthermore, diapirism associated with differential loading and regional compression mobilizing evaporites of the Carboniferous Otto Fiord Formation, had initiated by Middle Triassic and was contemporaneous with sedimentation throughout the Mesozoic (Boutelier et al., 2010; Embry \& Beauchamp, 2008).

During the Middle Jurassic to earliest Cretaceous ongoing rifting and the initiation of sea floor spreading in the Amerasian Basin coincided with possible rifting of Crockerland isolating the northwestern margin of the Sverdrup Basin and forming the Sverdrup Rim. During the Cretaceous the Sverdrup Rim separated the Sverdrup Basin from the Amerasian Basin to the north and with rising sea levels a narrow cratonic seaway connected the Sverdrup Basin to the Canadian Western Interior Sea. The Sverdrup Rim uplifted during the early Cretaceous and disconnected the Chukchi Basin from the Sverdrup Basin, causing a widespread sub-aerial unconformity, and first order sequence boundary (Embry, 1991, Embry \& Dixon, 1990, Embry \& Beauchamp, 2008). During the Cenomanian, the initiation of sea floor spreading in the Amerasian Basin resulted in high rates of subsidence and the Sverdrup Rim was transgressed. The volcanics of the Strand Fiord Formation are the result of this seafloor spreading and an active mantle plume throughout the late Cretaceous. The volcanics intercalate with the Bastion Ridge and the Hassel formations as found on northern Axel Heiberg Island. The shales of the overlying Kanguk Formation are a testament to the rapid transgression 
caused by increased subsidence in the Sverdrup Basin and eustatic sea-level rise (Embry \& Dixon, 1990; Embry, 1994; Kominz et al., 2008).

Although Crockerland was a source of sediment throughout the early Mesozoic, by the late Jurassic this region only acts as a minor source of clastic input. During the Cretaceous, most of the sediment influx is from the south and east, the Greenland and North American craton and the Ellesmerian Fold Belt, consisting of mainly Devonian siliciclastics (Embry \& Beauchamp, 2008; Embry, 1992, 2009).

Ellef Ringnes Island extends from the distal northern rim of the Sverdrup Basin to the basin axis (fig. 1). Numerous evaporite diapirs mobilized from the Carboniferous Otto Fiord Formation penetrate the center of the Sverdrup Basin, notably Ellef Ringnes, Amund Ringnes and Axel Heiberg Islands (Thorsteinsson, 1974), with emplacement initiating as early as mid Triassic (Boutelier et al., 2010). Hoodoo Dome itself is found on the southern-most peninsula of Ellef Ringnes Island, Meteorologist Peninsula, with an elongate shape that follows regional anticlines (Stott, 1969; Boutelier et al., 2010). Furthermore, thinning and onlapping of strata, up to and including the Hassel Formation with respect to Hoodoo Dome (fig. 2), indicates that diapir emplacement may have continued into the late Cretaceous (Gould \& Demille, 1964; Boutelier et al., 2010).

\subsection{Stratigraphy}

Detailed lithostratigraphic and sequence stratigraphic reviews have been published in Trettin (1991) and Embry \& Beauchamp (2008) for the Canadian Arctic Archipelago and the Sverdrup Basin, respectively. The Cretaceous on Ellef Ringnes Island is characterized by several nearshore and deltaic to offshore marine facies changes 
separated into lithostratigraphic units including in ascending order the Deer Bay, Isachsen, Christopher, Hassel, Kanguk and Expedition formations (fig. 3). This study focuses on the uppermost Albian Christopher Formation, Upper Albian to Lower Cenomanian Hassel Formation, and the Cenomanian to Maastrichtian Kanguk Formation.

The Christopher Formation is a widespread, thick unit of marine siltstones and shales, originally described by Heywood (1957) and refined by Stott (1969), and Balkwill and Hopkins (1976). It is an erosive and recessive siltstone and mudrock dominated unit, which, at Hoodoo Dome, had minimal exposure, though previously measured to a thickness of $850 \mathrm{~m}$ (Balkwill \& Hopkins, 1976) and described as two informal subunits. The Christopher Formation was interpreted as deposited in an offshore setting (Hopkins and Balkwill, 1973; Sliter, 1981). The formation has a gradational contact to the overlying Hassel Formation. Prodelta facies associated with the uppermost Christopher Formation gradually change to deltaic shoreface and shallow shelf sands throughout the basin.

The Hassel Formation is variable in thickness across the Sverdrup Basin, and was originally defined by Heywood $(1955,1957)$ at Isachsen Dome, Ellef Ringnes Island, as $550 \mathrm{~m}$ thick. This was later complimented through work by Hopkins and Balkwill (1973) and Balkwill and Hopkins (1976) with a locality east of Hoodoo Dome to approximately $300 \mathrm{~m}$ of strata. Mapped extensively within the Sverdrup Basin, the Hassel Formation can be found to represent deltaic to shoreface and nearshore sedimentation, with both marine and fluvial components (Hopkins \& Balkwill, 1973; Embry \& Beauchamp, 2008; Embry \& Dixon, 1990, 1994; Galloway et al., 2012). 


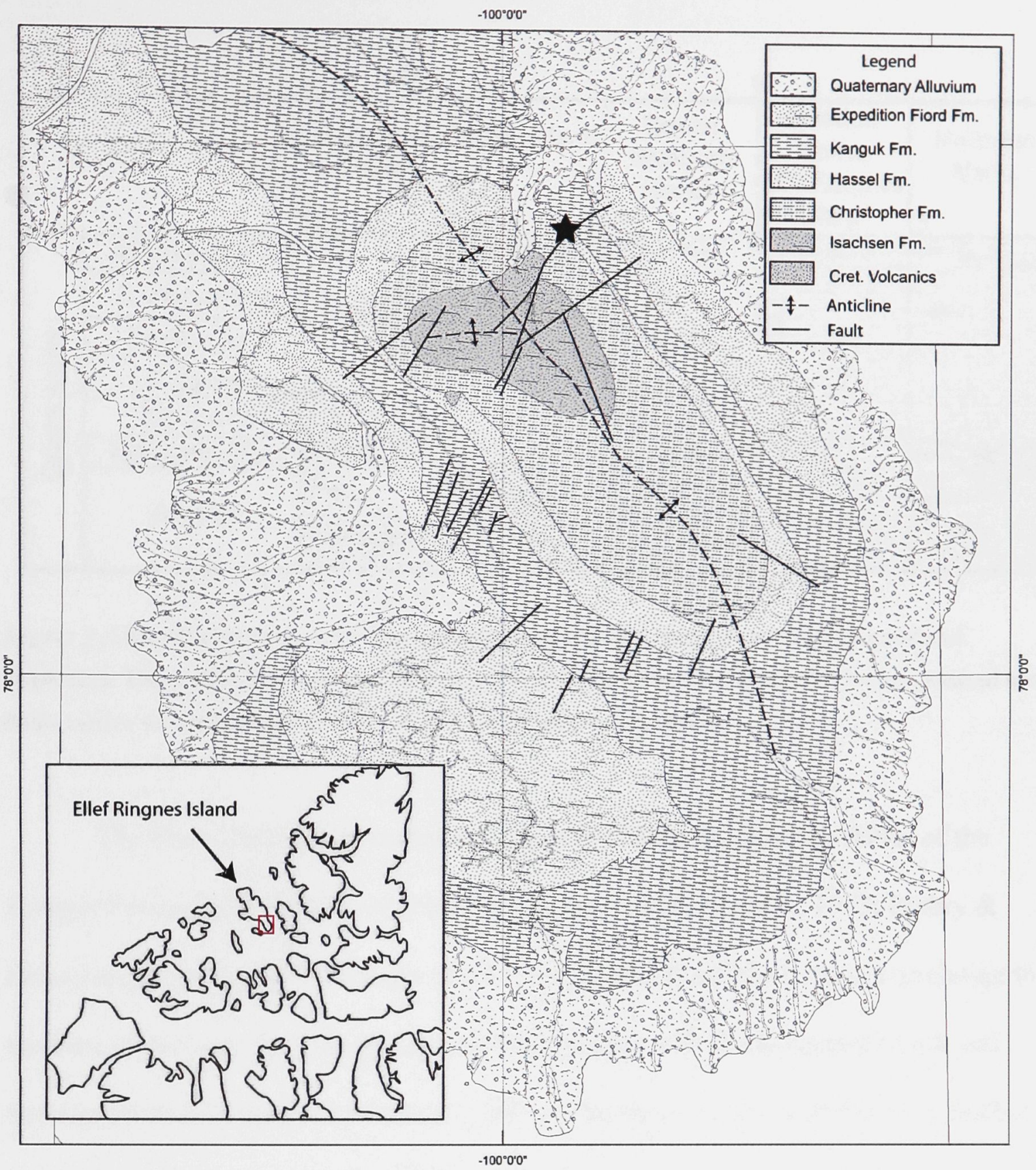

Figure 2: Geologic map of Hoodoo Dome on Ellef Ringnes Island, redrafted from Stott (1969). Inset shows location of Hoodoo Dome relative to the Canadian Arctic Archipelago. Star marks study locality. 


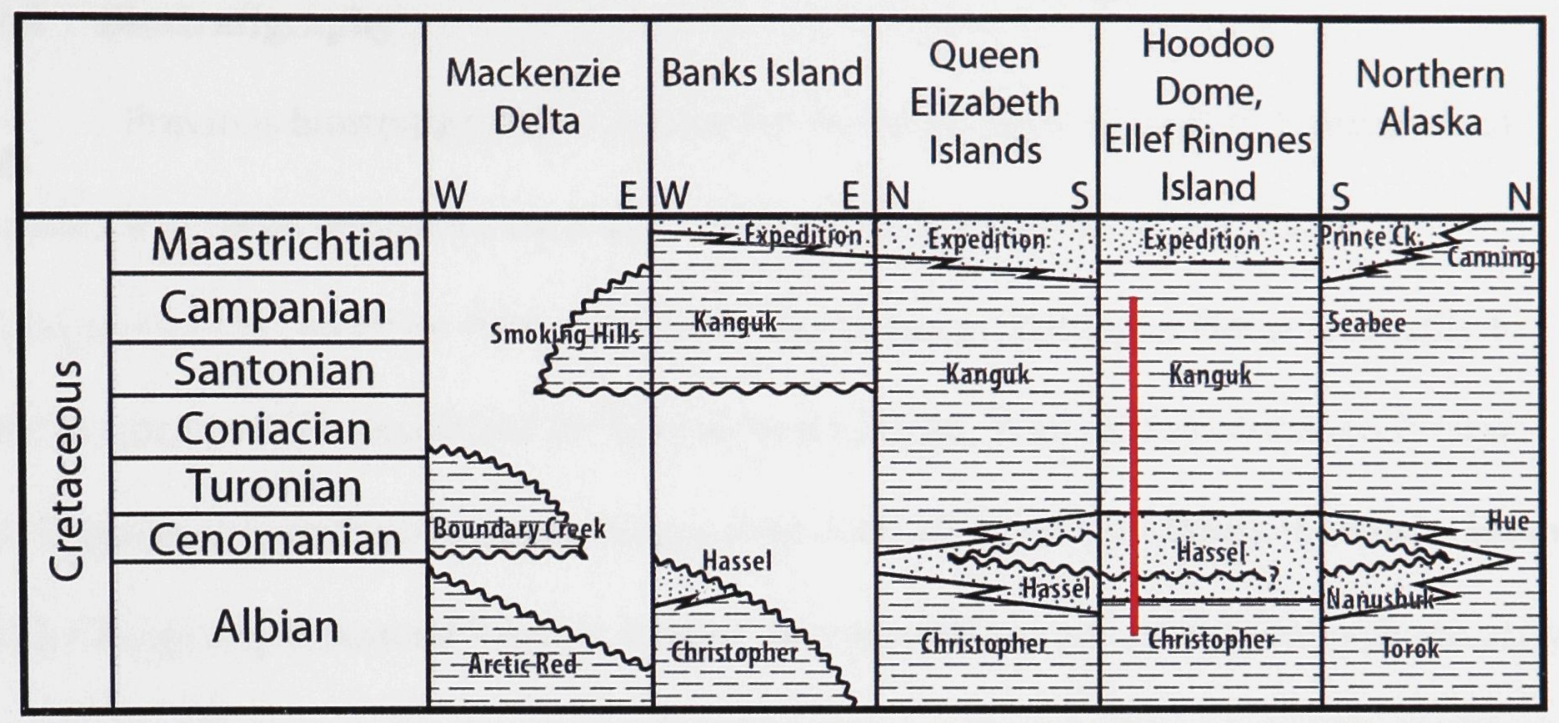

Figure 3: Lithostratigraphic correlation chart illustrating the lateral variation in units and sequences. The section studied here (marked with the red line) is the measured section located near basin center on Ellef Ringnes Island. After Embry \& Dixon (1992).

The Hassel Formation is sharply capped by black organic rich shales of the Kanguk Formation indicative of distal facies (Balkwill \& Hopkins, 1973; Embry \& Beauchamp, 2008). It is a widespread and pan-basinal distal black shale, correlating to the west of the basin into the Mackenzie Delta region with the Boundary Creek and Smoking Hills formations, and further still into Northern Alaska with the Hue, Seabee and Canning formations (Embry \& Dixon, 1992; Tappan, 1962). Núñez-Betelu et al. (1994) noticed a change in organic matter within the Kanguk Formation from marine to terrestrially derived. The Expedition Formation signals the return to deltaic sedimentation (Embry \& Beauchamp, 2008). 


\subsection{Biostratigraphy}

Previous biostratigraphic work for the Sverdrup Basin is limited. Foraminiferal studies have been performed by Sliter (1981) including sections of the Albian Christopher Formation on Amund Ringnes Island and at Helicopter Dome, a locality to the northeast of Hoodoo Dome on Ellef Ringnes Island. Wall (1983) addressed Jurassic to Cretaceous foraminiferal assemblages from Axel Heiberg and Ellesmere islands. From Ellef Ringnes and Amund Ringnes Islands, two assemblage zones were defined; the early Albian Gaudryina tailleuri, and middle Albian Verneuilinoides borealis zones, marking the lower and upper Christopher Formation, respectively (Sliter, 1981). Further study by Wall (1983), subdivided the Jurassic and Cretaceous of the eastern Sverdrup Basin into eleven assemblages based on foraminifera, correlated with macrofaunal associations. The faunas found in the Albian through Campanian strata correspond to more southern localities; the Albian suites correspond well throughout much of the Western Interior and Arctic suites, and the Turonian through Campanian correspond with suites in Alberta and Saskatchewan (Wall, 1983). Further, Wall (1983) noted the presence of radiolaria above the Hassel-Kanguk boundary, in the Turonian, notably Spongodiscus cf. multus, and Dictyomitra sp. higher up still within the Santonian. This corresponds with previous studies through the Cretaceous of Alberta, where the rare presence of radiolaria is found in correlative formations through the Western Interior Sea (Wall, 1975).

Correlative studies from Northern Alaska were performed by Tappan (1960, 1962) where a "paper-shale" unit interbedded with minor bentonites, and containing rare foraminifera and fishbone fragments, were found within the Seabee Formation spanning the Cenomanian-Turonian boundary (fig. 3). Tappan (1962) also noticed rare planktonic 
foraminiferal specimens, which allowed for correlations to Turonian strata associated with the Greenhorn sea-level highstand of the Western Interior Sea.

Several palynological studies have been published for the late Cretaceous of the Sverdrup Basin, with initial descriptions of palynofloras put forward by Hopkins and Balkwill (1973) and refined later by Balkwill et al. (1982). Most recently, Galloway et al. (2012) described and correlated the Hassel Formation of this section from Ellef Ringnes Island to that of reputed lithologies from Eclipse Trough on Bylot Island. The Hassel Formation was informally divided into two members. The lower member was interpreted as a marine, upward shallowing, progradational unit, genetically related to the prodeltaic upper Christopher Formation. The upper member was described as being marine to terrestrial sandstones and coals indicative of fluvial settings (Hopkins and Balkwill, 1973; Galloway et al., 2012). Further, palynological age constraint for the Hassel Formation was found to be mid to late Albian to Cenomanian, with faunas supported by a previous radiometric age $(\mathrm{U}-\mathrm{Pb} 95.3 \pm 0.2 \mathrm{Ma})$ from correlative intercalated Strand Fiord basalts within the Bastion Ridge Formation on Northern Axel Heiberg Island, coeval with the uppermost Hassel Formation (Trettin \& Parrish, 1987; Galloway et al., 2012). The palynoflora of the Kanguk Formation in the eastern Sverdrup Basin was further described and re-characterized by Núñez-Betelu et al. $(1992,1994)$, integrating Rock Eval data to delineate hydrocarbon potential within the formation. 


\section{Chapter: Methods}

Outcrop conditions at Hoodoo Dome required measurement of five separate sections that were stratigraphically correlated by the use of stratigraphic marker beds such as coal beds, bentonites and distinctive lithology. These sections, located on the

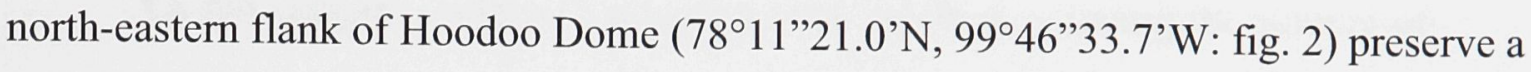
total of $\sim 190 \mathrm{~m}$ of Hassel Formation and $300 \mathrm{~m}$ of Kanguk Formation, with the approximate meterage accounting for a gradational contact with the underlying Albian Christopher Formation. A total of 65 rock and sediment samples were taken throughout the uppermost Christopher Formation and Hassel Formation for lithological analyses, and 35 subsamples from the section were submitted for Rock Eval Pyrolysis. Similarly, 71 sediment samples were taken throughout the Kanguk Formation for bistratigraphy and lithology, excluding bentonite samples 65 were split and submitted for whole rock geochemistry (ICP-MS) and Rock Eval Pyrolysis.

\subsection{Sedimentology and Geochemistry}

The geomorphology of Ellef Ringnes Island calls for caution, sedimentologically speaking, especially within the Kanguk Formation, as slumping and mass wasting within the thawed sediment layer on top of the permafrost surface is evident throughout the section. In order to reduce this source of error, much of the sampling of the Kanguk Formation took place directly from permafrost-frozen beds of shale, where bedding angles were preserved and consistent with those taken throughout the rest of the section. In areas where bedding appeared proper and visible, cryo-sampling was not necessary in a strict sense but was often still used for standardization. One concern with this sampling 
is the effect of cryoturbation on the samples, both taphonomically, as test preservation could be reduced through the freeze and thaw of water within the pore spaces of the samples, and lithologically, with overburden and mass wasting introducing foreign material through years of frost heaving.

Of the samples collected, very few were lithified, reducing the amount of processing necessary. Within the Hassel Formation specifically, the only lithification found within the section were ferruginous mudstones and silty sandstones, and concretionized beds rich in iron. The bulk of the "sandstones" were unlithified, friable, and very poorly indurated, so much so that a trowel was used for sampling for most of the sandstones of the Hassel Formation. A total of 100 samples through the entire section, as detailed above, were submitted for Rock Eval Pyrolysis performed at the Geological Survey of Canada, Calgary. The lithified ferruginous and concretionized beds sampled consisted predominantly of pebble beds.

\subsection{Micropaleontology}

A total of 71 samples were collected from mudrock and shale intervals throughout the section. Samples collected were originally processed for foraminifera using the method denoted by Then and Dougherty (1982). This process revealed that the Kanguk section yields poor foraminifera assemblages, but rich radiolarian assemblages of resistant and strong specimens of Spumellaria and Nassellaria, which were then chosen for study. However, since the processing method used was originally designed for the separation of foraminifera, residues were not as concentrated with radiolaria as could be expected from other separation techniques (Pessagno, 1976), though none of the 
radiolarian components were lost. Furthermore, some of the radiolaria show rare flattening and abrasion in addition to broken tests resulting in varying preservation.

Analysis and picking of the sample residues of sand size particulate ( $>63 \mu \mathrm{m})$ was performed on an Olympus dissection microscope with Olympus 20x oculars and a fine brush. Specifically within the Hassel and lowermost Kanguk formations, many samples were barren or contained poorly preserved specimens. Qualitative estimates of abundance were evaluated by visual inspection as a number of radiolarian specimens per picking tray (similar to Baumgartner, 1992). Further, the abundance ratio between Spumellaria and Nassallaria was estimated to further interpret the relationship between radiolarian and paleoceanographic signals (Bartolini et al., 1999; Vishnevskaya \& De Wever, 1998). Abundances were defined as:

0 (Barren) - No radiolaria found in residue (at least five trays),

1 (Rare) - Less than 10 radiolaria per tray of residue,

2 (Few) - 10-99 radiolaria per tray of residue,

3 (Common) - 100-199 radiolaria per tray of residue,

4 (Abundant) - 200-299 radiolaria per tray of residue,

5 (Deluge) $-300+$ radiolaria per tray of residue.

The abundance of radiolarian tests is reliant on preservation. Recrystallization of the opaline silica, mechanical abrasion and host rock lithology, as well as effects of cryoturbation can effect radiolarian preservation. Following Baumgartner (1992), qualitative assessment of radiolarian preservation was defined as:

$0=$ Indeterminate, barren samples

$1=$ Very poor preservation, only molds and fragmented, abraded forms. 
$2=$ Poor preservation, mostly broken tests, still many molds and fragmented forms. 3 = Moderate preservation with few radiolarian tests showing mechanical erosion of extremities and spines, ornamentation is visible. Most forms found are identifiable. 4 = Good preservation with many radiolarian tests complete, very few forms showing overgrowth, occasional infill or cement present. Most forms found are identifiable. $5=$ Very good preservation with most radiolarian tests complete with spicular and delicate tests mostly complete. Very rare overgrowth, infill or cement present, with practically all forms identifiable.

Further analysis of the radiolaria included Scanning Electron Microscope (SEM) and Back Scatter Electron Microscope (BSEM) photography for species identification using a Tescan Vega-II XMU VPSEM at Carleton University. Preparation of SEM stubs was done using an Olympus SZX9 dissection microscope and mounting key forms using Ted Pella, inc. double-coated conductive carbon tape.

This study dominantly utilized the original descriptions and taxonomy put forward by Campbell \& Clark (1944), as well as those descriptions found in Pessagno (1976, 1977), De Wever et al. (2001), and the InterRAD- Mesozoic Radiolaria database (Baumgartner et al., http://www2.unil.ch/interrad-mrd, 2012). 


\section{Chapter: Results}

\subsection{Lithostratigraphy}

Within the measured section of the uppermost Christopher, Hassel and Kanguk formations 13 different facies are recognized. Each facies is characterized by lithology, faunal and floral content, organic geochemical signature, ichnofossil and ichnofacies and interpreted energy levels and environments (Table 1). Figures 4 and 5 illustrate the distribution of each facies as found in the section and examples of facies expressions in outcrop are given. The facies occurrence is for the most part discussed in stratigraphic order.

\section{Facies 1: Mudrock}

The mudrock facies (Facies 1) is characterized by dark grey brown to black shale and siltstones, with rare lenticular interlaminae of arenaceous sandstone, where sandstones are poorly lithified. This facies is found at the gradational boundary between the Christopher and the Hassel formations as well as within the Hassel Formation succession (fig. 4) and is moderately to poorly indurated. Rare vertical burrows crosscut lenses of laminated very-fine to fine grained sandstones. This facies is interpreted to correlate to offshore marine deposition, as storms may attributed to the deposition of rare sandstone interlaminae.

\section{Facies 2: Interbedded Mudrock and Sandstone}

The interbedded mudrock and sandstone facies (Facies 2) occurs in the lower Hassel Formation (fig. 4) and consists of dominantly dark grey to dark brown mudstones 
and siltstones interbedded by very-fine to fine grained arenaceous sandstone, where the amount of mud is variable, found to be between $40-70 \%$ in the lower portions of the section, to as little as $10 \%$ moving stratigraphically upwards (fig. 4 A,B,C). Decimeter scale hummocky cross stratification is evident as multiple trough-cross bed sets are seen encased in mud. Bioturbation is low within this facies, preserving only minor vertical burrows. Where there is a decrease in mud and interbeds of mud and silt amount to 10$30 \%$, the facies is dominated by fine-grained arenaceous sandstone with mud and silt found generally as drapes on cross-stratified sands and thin beds within hummocks. Trough and hummocky cross stratification is common and $10-20 \mathrm{~cm}$ in scale.

Bioturbation is still low, but Skolithos Ichnofacies vertical burrows, including Bergaueria (fig.4A), were identified. This ichnofossil is characteristic of normal marine conditions (Pemberton et al., 2001). The ichnofacies and hummocky cross-stratification indicates a wave- or tidal-influenced nearshore to lower shoreface environment.

This facies is interpreted to represent a gradation from the offshore transition zone at the storm weather wave base (SWWB) to lower shoreface deposition, where either the effect of minor sea-level fluctuations or change in sediment source can be pronounced varying the proportion of mud and sand considerably, as well as the ichnofossil content and fabric. Found within the lower Hassel Formation, the sandstone content increases stratigraphically upwards, grading into coarser grained sands in the upper Hassel Formation. From the increase in sand, this facies could be forced into the lower shoreface or the interface of the outer delta-front platform and the prodelta slope (Clifton et al., 1971).

Table 1 (next 2 pages): Facies of the uppermost Christopher, Hassel and Kanguk formations with descriptions and interpretations. 


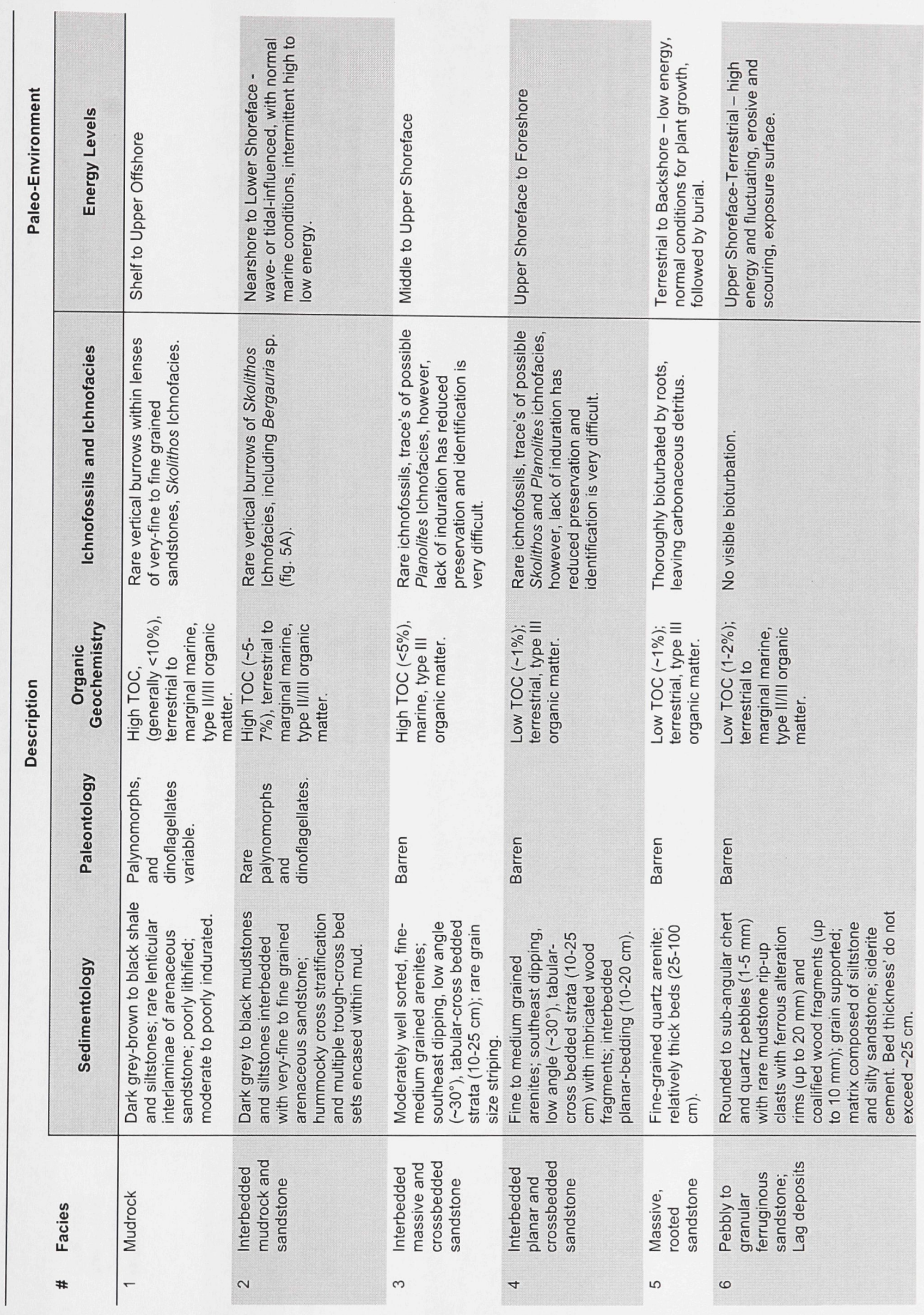




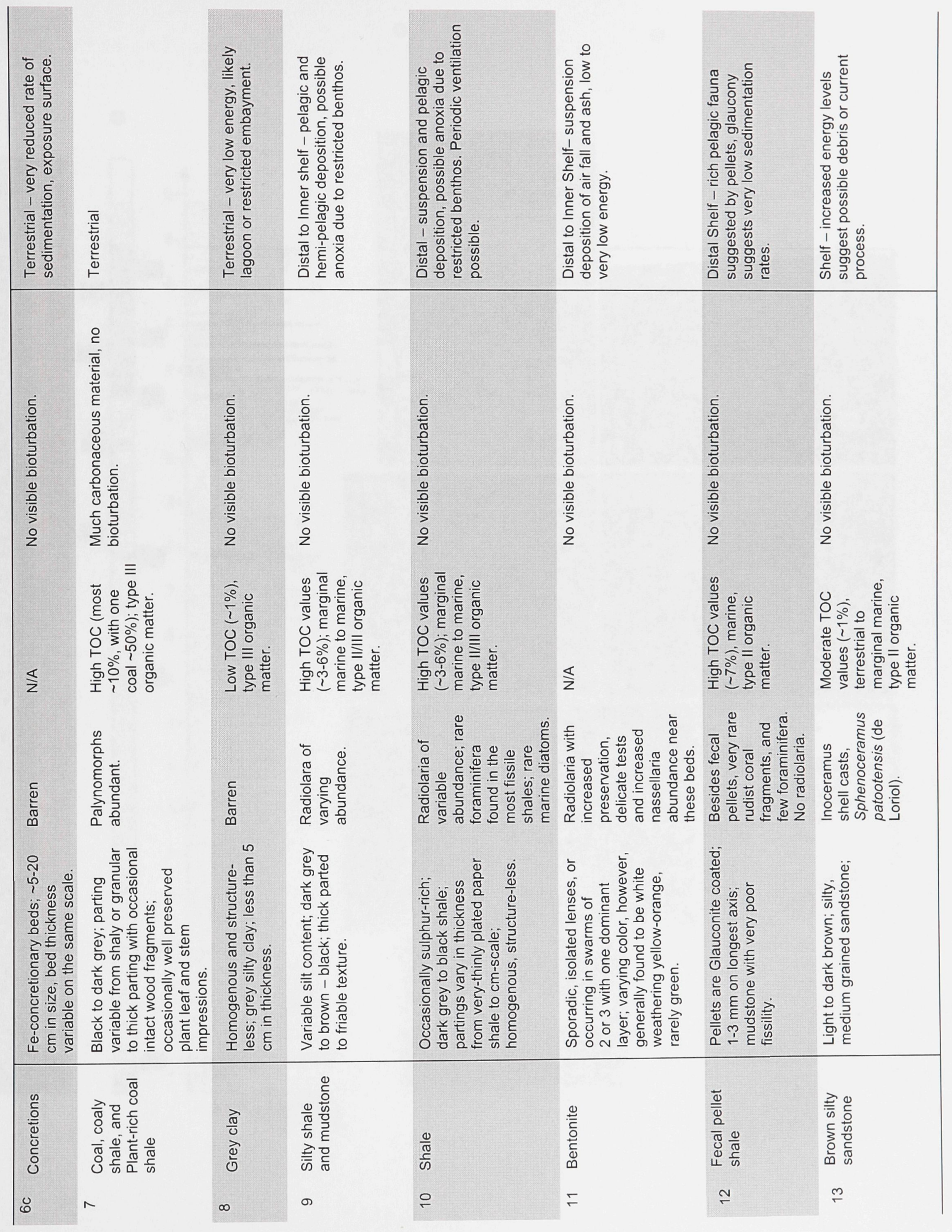



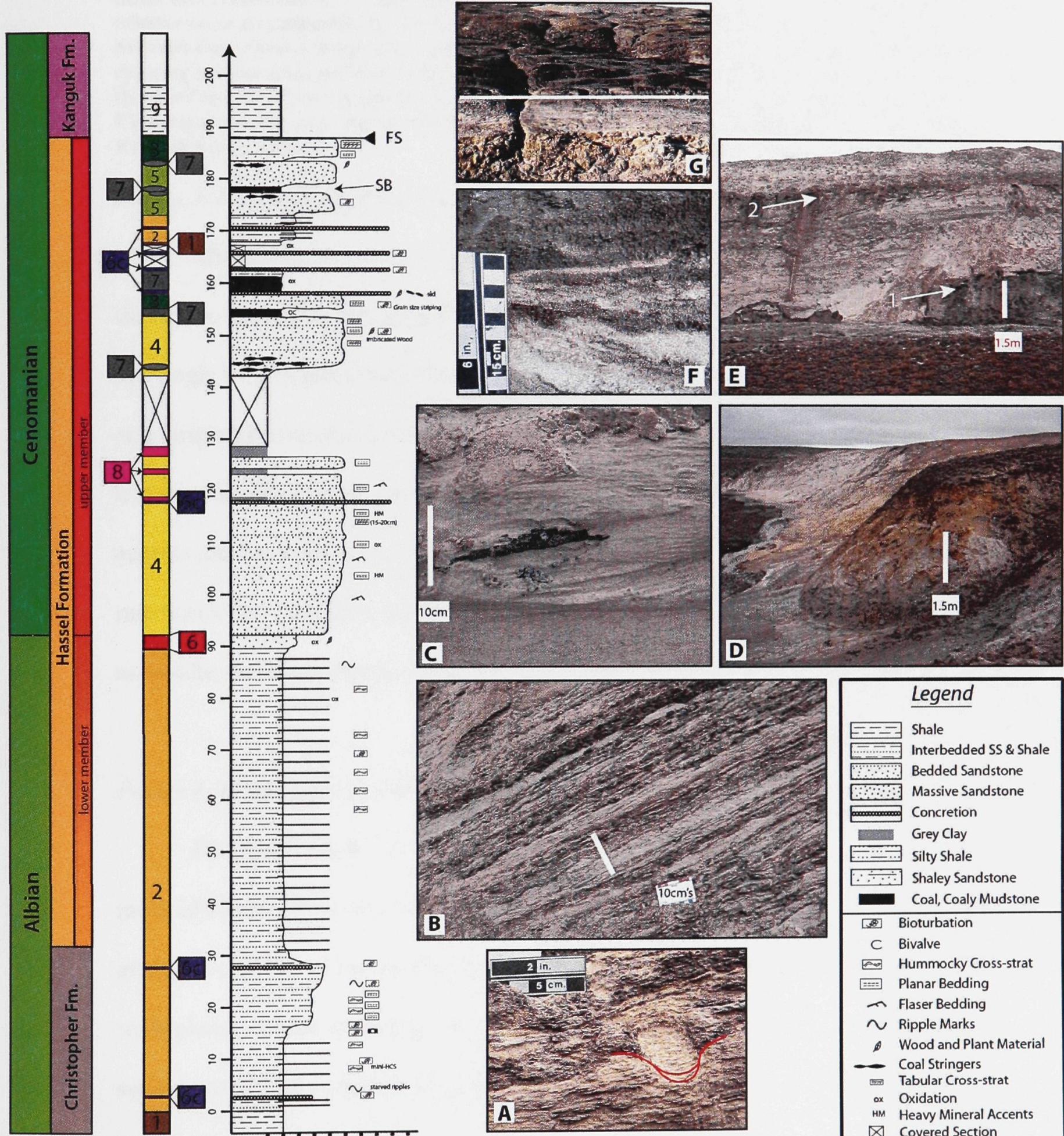

$\left.4\right|_{8}$
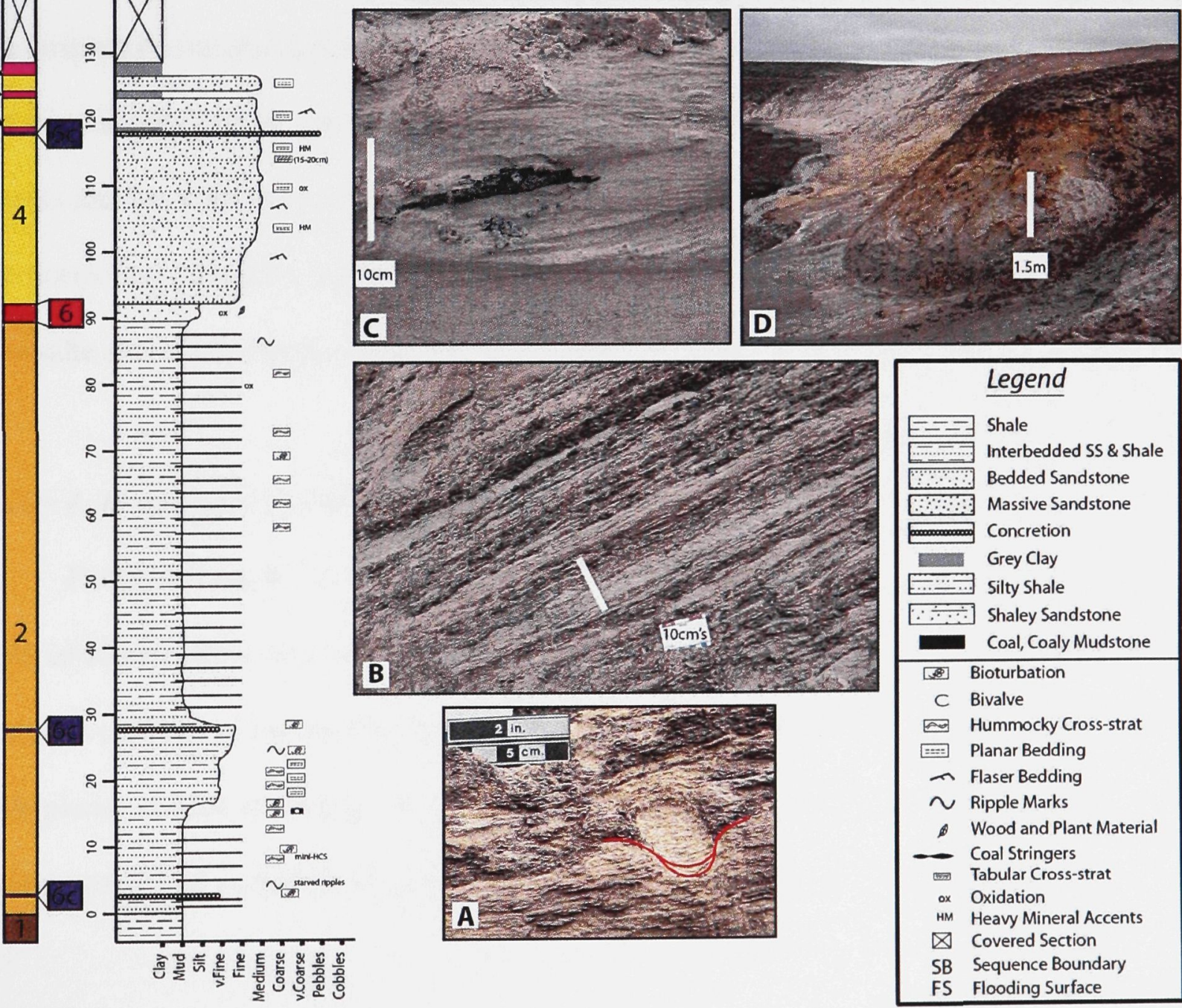

......... Interbedded SS \& Shale

Bedded Sandstone

Massive Sandstone

Concretion

Grey Clay

$\ldots \ldots$.... Silty Shale

$\because \div$ Shaley Sandstone

Coal, Coaly Mudstone

Bioturbation

C Bivalve

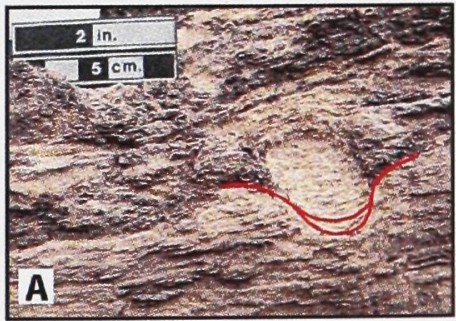

Hummocky Cross-strat

Planar Bedding

^ Flaser Bedding

ح Ripple Marks

- Wood and Plant Material

_ Coal Stringers

Tabular Cross-strat

ox Oxidation

HM Heavy Mineral Accents

$\otimes$ Covered Section

SB Sequence Boundary

FS Flooding Surface 
Figure 4: Uppermost Christopher and Hassel formations detailed measured section showing formations, facies, and lithology. Legend to right. A) Bergauria sp. cross cutting hummocky crossstratification within the uppermost Christopher Formation. B) Interbeds of mudstone and high angle cross-stratified sandstones in the lower Hassel Formation, showing gradation of the Christopher muds into Hassel sands. C) Imbricated wood fragments within the upper Hassel Formation overlying tabular cross stratification. D) View looking up section of the Hassel Formation at the boundary between the informal lower and upper members (Galloway et al., 2012). E) Upper Hassel Formation showing preservation and lack of lithification within the unit, note the coaly mudstone at the base of the outcrop (1) and the concretionary horizon near the top (2), which preserves a pebble bed. F) Close up of contact between the Hassel and Kanguk formations. G) Contact between Hassel and Kanguk Formations.

\section{Facies 3: Interbedded Massive and Crossbedded Sandstone}

Moderately well sorted, fine-medium grained arenites compose Facies 3 within the mid to upper Hassel Formation. Massive beds are interbedded with southeast dipping, low angle $\left(\sim 30^{\circ}\right)$, tabular-cross bedded strata found in bed sets of $10-25 \mathrm{~cm}$ (fig. 4$)$. Grain size striping is common in the cross bedded horizons, grading from very fine to medium and occasionally coarse grained quartz sand (Pemberton et al., 2001). Heavy mineral accents are also common on the foresets of the crossbeds. The massive strata preserve rare horizontal Planolites burrows of the Skolithos Ichnofacies. This facies is interpreted as middle shoreface (Pemberton et al., 2001).

\section{Facies 4: Interbedded Planar and Crossbedded Sandstone}

Facies 4 is similar to Facies 3, with the distinction of abundant wood and plant material found within the upper Hassel Formation. Imbricated wood fragments found along the surfaces of low angle, tabular-cross beds, found alternating with decimeterscale planar-bedded strata (fig. 4C) indicate that this facies represents a more proximal setting interpreted as middle to upper shoreface including beach environment. 


\section{Facies 5: Massive, Rooted Sandstone}

Massive, bioturbated sandstones are found in the uppermost Hassel Formation, directly beneath plant-rich coals and coaly shales. Facies 5 consists of massive, finegrained quartz arenite that is at times thoroughly bioturbated by roots, leaving carbonaceous detritus. The beds are relatively thick, 25 to $100 \mathrm{~cm}$, and occasionally separated from the coals by rusty, sideritic mudstone facies. A marginal marine to coastal plain environment is postulated for this facies.

\section{Facies 6: Pebbly to Granular Sideritic (Ferruginous) Mudrock}

Rare lithified beds within the upper Hassel Formation (fig. 4E) consist mainly of rounded to sub angular chert and quartz pebbles $(1-5 \mathrm{~mm})$ with rare mudstone rip-up clasts with ferrous alteration rims (up to $20 \mathrm{~mm}$ ) and coaly wood fragments (up to 10 $\mathrm{mm}$ ), which have been preserved within a ferruginous matrix. These are interpreted as ravinement and transgressive lag deposits. Bed thicknesses do not exceed $\sim 25 \mathrm{~cm}$ and lateral continuity suggests that these lags could have been caused by localized flooding events. Confinement indicating a possible channel was not observed in the outcrop.

\section{Facies 7: Coal, Coaly Shale, and Plant-rich Coal Shale}

Facies 7 encompasses several coals of varying organic and kerogen content that were found within the upper portion of the Hassel Formation (Galloway et al., 2012). This facies is generally of terrestrial nature, however, few samples indicate the influence of marine algal sources by way of their organic matter (figs. $6 \& 7$ ). These coals are interpreted to be swamp, restricted to rarely inundated lagoon, or peat deposits, thus 
producing type III (Humic) coals, with possible transitional type II/III (LipitinicPlanktonic/Humic) coals.

Facies 8: Grey Clay

Often found beneath smaller lenses of coaly shale in the upper Hassel Formation (Facies 7) and above sandstones of Facies 4, Facies 8 consists of a clay layer that identifies a marked reduction in energy and change in depositional setting. Lack of bioturbation within this unit identifies that water conditions (e.g. salinity) at this time may not have been suitable for marine benthos. This facies has been interpreted as a lake or restricted embayment within the terrestrial to marginal marine transition zone.

\section{Facies 9: Silty Shale and Mudstone}

Facies 9 to 13 are associated with the Kanguk Formation. The boundary between the Hassel and Kanguk formations is sharp transitioning from Facies 3 to Facies 9 (fig. 4 F, G). It is variable in its silt content; however, these silty mudstones can have a thick to friable texture and are generally dark grey to black in color, few having a slight brownish color. With both Facies 9 and 10, further division is possible based on organic geochemistry (see Chapter 4.2), as both lithologies; shale and silty shale and mudstones, are found within both the lower and upper subdivision of the Kanguk Formation.

\section{Facies 10: Shale}

Facies 10 is generally found intermittently with Facies 9 within the Kanguk Formation (fig. 5). This facies is occasionally sulphur-rich and dark grey to black thinly 
plated shale. Neither visible sedimentary structures, nor discernable bioturbation, were observed. This facies is interpreted to reflect a distal basin, deep-water environment (Stow et al., 2001; Shanmugam, 2006).

\section{Facies 11: Bentonite}

Bentonites are found persistently throughout of the Kanguk section, occasionally sporadic and isolated lenses, though most times in swarms of 2 or 3 . Variation in thickness ranges from centimeter to decimeter scale, however, most do not have uniform thickness and can vary occasionally over a few meters of lateral extent. Most are ash-rich, as are the shales surrounding the bentonite, and weather generally to white, yellow and orange, and rarely green-grey (fig. 5 C, F). Bentonites remain under study for geochronology.

\section{Facies 12: “Glauconite” Pellet Shale}

Facies 12 describes a thin bed in the upper Kanguk Formation and consists of pellets, which are glaucony coated and have a cracked exterior appearance. Pellets are 1$3 \mathrm{~mm}$ in length and are entrained in a mudstone matrix. This facies represents decreased sedimentation rates based on the presence of the glaucony coatings (Odin et al., 1988). These pellets are tentatively interpreted as fecal pellets that would suggest the presence of a productive pelagic and possibly benthic fauna producing coprolites (Chin et al., 2008). 


\section{Facies 13: Brown Silty Sandstone}

In the uppermost portion of the Kanguk Formation section, preserved

Sphenoceramus patootensis (de Loriol) fossils are found within light to dark brown silty sandstone beds (fig. $5 \mathrm{G}$ ). Lithified and well exposed, this silty sandstone unit is at most $25-50 \mathrm{~cm}$ thick that suggests an increase in energy. Associated with Facies 12, this facies is restricted to the uppermost part of the Kanguk Formation, and further coincides with a shallowing of the basin and an increase in terrestrial (type III) organic matter. This facies is differentiated from Facies 2 by the macrofossil content. 


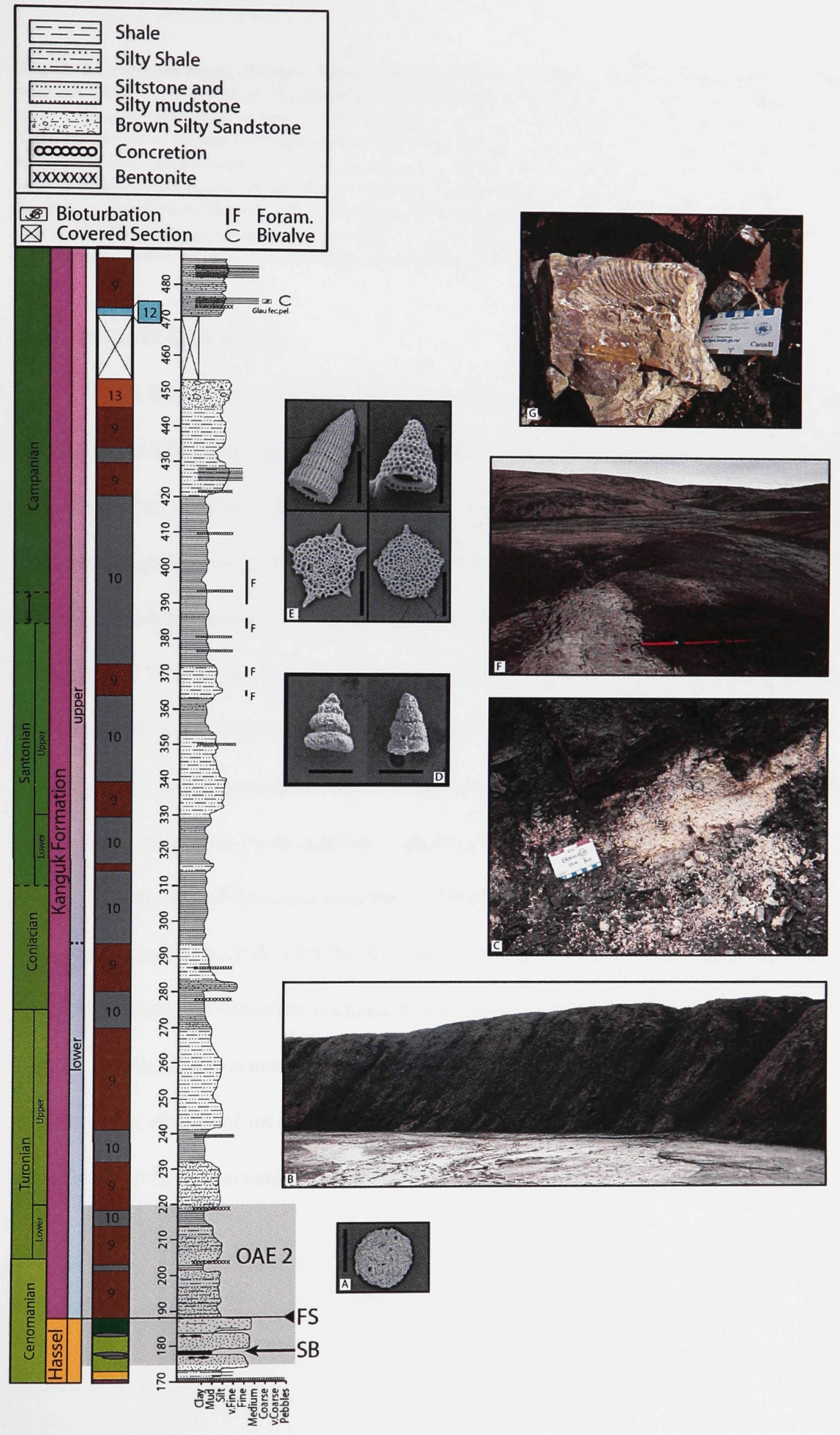


Figure 5 (previous page): Kanguk Formation detailed measured section showing formations, facies, and lithology. A, D, E) Most abundant radiolaria found within these intervals, illustrating generalized preservation as well. A) Spongodiscus sp. characterizes the Spongodiscids zone, D) internal molds of Santonian Nassellaria, tests were not preserved for species level identifications, E) (from top left, clockwise) Dictyomitra multicostata, Eostichomitra communis, Orbiculiforma (?) sp., and possible (?)Quinequecapsularia sp. showing increased preservation and diversity. B) View looking up section of the Kanguk Formation, note high bedding angle (cliff is approximately 25-30 m high). C) Bentonite, scale bar is $10 \mathrm{~cm}$ wide. F) Bentonite, pogo is $1.5 \mathrm{~m}$. G) Sphenoceramus patootensis within Facies 13 of the uppermost Kanguk Formation.

\subsection{Rock Eval Pyrolysis}

Rock Eval results returned three clearly defined groupings of kerogen type from the Hassel and Kanguk formations. The Hassel Formation is well defined with type III organic matter, with rare marine incursions of type II kerogen. A few anomalous samples with very high Hydrogen Index values $(\mathrm{HI}=\mathrm{S} 2 / \mathrm{TOC}$; figs. 6 \& 7) stem from low TOC values and fairly consistent or rarely increased S2 values, the second measured peak during Rock Eval Pyrolysis that corresponds to the pyrolysis of insoluble components of hydrocarbons and kerogens (Espitalie et al., 1977). This correlates with a terrestrial source for the organic matter within the regressive and progradational Hassel Formation, which bears numerous coals, and much plant debris from a deltaic source.

The Kanguk Formation possesses a broader range across both type II and III kerogen sources, which divides the Kanguk Formation into two members (figs. 6 \& 7 ). The lower Kanguk Formation is characterized by generally type II, marine derived organic matter, corresponding to roughly the first $100 \mathrm{~m}$ of the Kanguk Formation and identifying a section of increased organic preservation. The upper member is characterized by preservation of type III organic matter and reduced TOC values. 

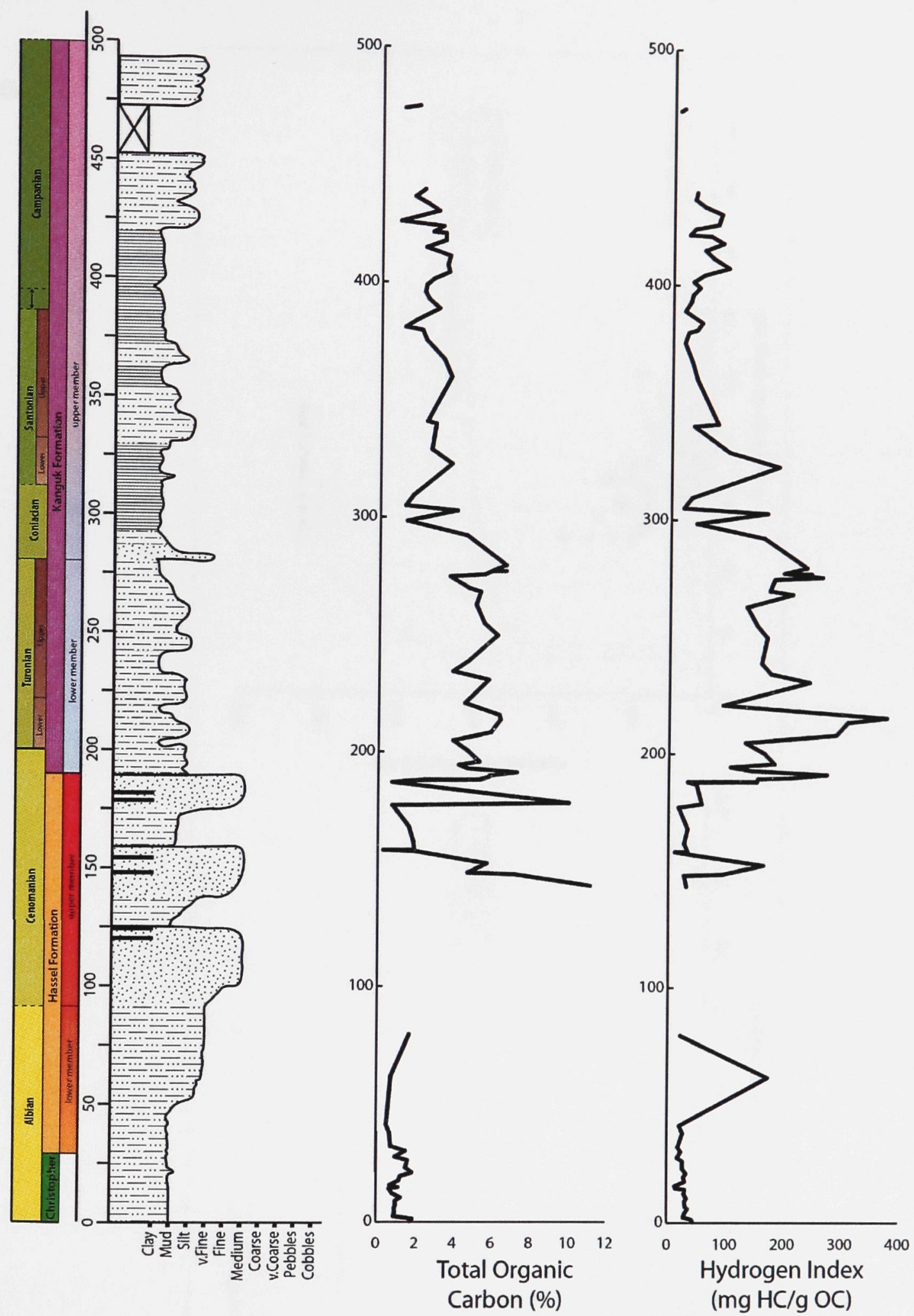

Figure 6: Simplified lithological log of the measured section at Hoodoo Dome compared to changes in Total Organic Carbon (TOC) and Hydrogen Index. Missing data through the Hassel Formation is due to sampling bias. 


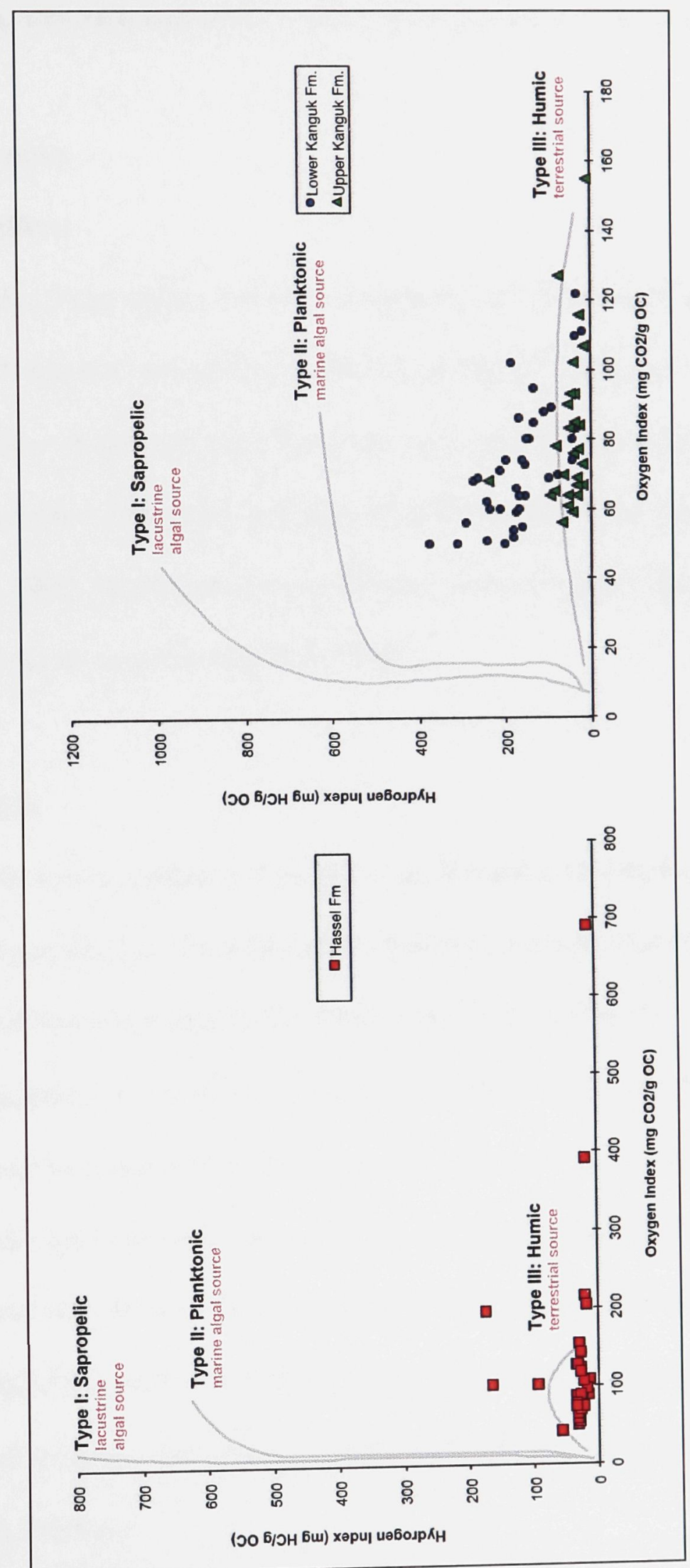


Figure 7 (previous page): Pseudo van Krevelen diagrams for the Hassel and Kanguk formations from Hoodoo Dome. Note the change in the $\mathrm{X}$ - and $\mathrm{Y}$ - axis scales between the two graphs.

\subsection{Biostratigraphy}

\subsubsection{Foraminifera}

Rare benthic foraminifera were found spanning the Santonian/Campanian boundary interval. Species such as Verneuilinoides fischeri Tappan and Haplophragmoides rota (Nauss) were found and correlated to reported occurrences in the uppermost Coniacian to Campanian Schrader Bluff Formation of the North Slope of Alaska (Tappan, 1962). Both species were also part of the Kanguk Formation of the Eastern Sverdrup Basin as studied by Wall (1983).

\subsubsection{Radiolaria}

Radiolaria occur abundantly throughout the Kanguk Formation and provide a valuable biostratigraphic tool. No published radiolarian zonation addressing the Cretaceous Boreal Sea was available for comparison. Thus, this study is the first attempt to provide a range chart of radiolarian species and a tentative zonation (figs. $8 \& 9$ ). Many of the preserved species have short ranges and in places have only been found in single samples, though there are a few robust species that are persistent throughout the Kanguk Formation (fig. 8). In comparison to lower latitudes (e.g. Empson-Morin, 1981; Bandini et al., 2006) Nassellaria and Spumellaria occur with low species diversities, resembling a high latitude assemblage as described by Filatova \& Vishnevskaya (1997) from the Russian Platform. 
Key nassellarian taxa include Amphiternis sp., Eostichomitra sp., Diacanthocapsa sp., and Dictyomitra sp. Most notable is the persistence of the spumellarian genera Spongodiscus and Orbiculiforma throughout most of the section, as well as Holocryptocanium in the lower portion of the section.

The basal portion of the Kanguk Formation, containing roughly the first 100 meters of the measured section, corresponds to poorly preserved spongy Spumellaria, consisting of mostly Holocryptocanium (?) barbuui Dumitrica, Archaeocenosphaera (?) sp., Spongodiscus (?) sp., and Orbiculiforma (?) sp. At the base of the Kanguk section, few forms are found appearing similar to Godia sp., however, the poor preservation does not allow for a positive identification (Plate 1). These spongodiscids and spongy Spumellaria persist for the duration of the section; even when Nassellaria are most dominant, spongy forms are still present (fig.8).

This poorly preserved "spongy" basal assemblage is followed by first occurrences of Nassellaria within the Turonian interval (fig. 8). Short-lived specimens characterize the Turonian interval. These rare species include Xitus spicularis Alieve and Amphiternis aff. stocki, however, they do not persist, and are found in only one sample amongst samples which have a strong dominance of spongodiscids and spongy Spumellaria. Interestingly though, beginning within this interval, increased radiolarian preservation is found to roughly coincide with bentonite occurrences increasing silica content (Bandini et al., 2006).

The presence of eostichomitrids heralds the beginning of a nassellarian radiation through the beginning of the Coniacian. Here the preservation and abundance of Nassellaria is noticeably greater, and is characterized by the dominance of E. carnegiense 
and Diacanthocapsa aff. cayeuxi. Although these species are very robust and long ranging, and persist for most of the remaining Kanguk Formation, there is a pronounced reduction in Nassellaria immediately after their radiation, where the preservation and abundance of all species is markedly reduced (fig. 8).

Nassellarian molds are the first evidence of the initiation of a radiation in the upper Santonian indicating radiolarian presence but poor preservation conditions for siliceous test. Unfortunately, these molds are too poorly preserved to determine species, although multi-segmented and of greater than 3-4 costae. In this interval Eostichomitra carnegiense and Diacanthocapsa aff. cayeuxi return, together with E.communis and A. aff. stocki. Following shortly thereafter still within the upper Santonian, Dictyomitra multicostata appears. All of these species have robust tests, mostly conical, and although only the cephalis and thorax, rarely the abdomen, is preserved of these tests, they are characteristic for the upper Santonian to Campanian interval of the Kanguk Formation. These species continue throughout the rest of this upper portion with rare occurrences of short ranging species. The fauna corresponds in their limited numbers, low diversity and robust species with described high latitude faunal assemblages (Vishnevskaya \& De Wever, 1998; Erbacher \& Thurow, 1998).

Radiolarian assemblage changes and individual species ranges result in a tentative zonation for the Cenomanian to Campanian aged Kanguk Formation (fig. 9). The zones are described in ascending order.

The Spongodiscus Zone is defined by the First Appearance Datum (FAD) of spongy Spumellaria and Spongodiscus sp. appearing in the latest Cenomanian though these species range through most of the Kanguk Formation. An additional element of this 
zone is Holocryptocanium barbuui Dumitrica that ranges into the Coniacian. The lower boundary of this zone is environmentally controlled and correlates to the abrupt deepening of the basin at the Hassel/Kanguk boundary. It is expected that this FAD would be somewhat diachronous across the Sverdrup Basin.

The short range of Xitus spicularis defines a subzone within the Spongodiscus Zone, marked by the FAD of Amphiternis aff. stocki (Campbell \& Clark), Orbiculiforma aff. sacramentoensis Pessagno, and Xitus spicularis Alieve. This zone also marks the first radiation of Nassellaria within the late Turonian.

The Eostichomitra Zone is defined by the FAD of eostichomitrids (Eostichomitra sp. B, and Eostichomitra. aff. carnegiense (Campbell \& Clark), though their general lack of preservation makes identification to species level difficult. Some of these forms bear resemblance to Xitus spicularis (Alieve) and X. alievi (Foreman) from the North Atlantic, though smaller (Thurow, 1988). This zone characterizes a radiation of Nassellaria in the early Coniacian, together with the FAD of Diacanthocapsa aff. cayeuxi (Squinabol). The base of this zone is dominated by Nassellaria, however, the top of this zone is poorly constrained as there is a marked reduction in preservation and possible extinction at the beginning of the Santonian.

The Dictyomitra multicostata Zone marks the early Santonian, by the FAD of Dictyomitra multicostata Zittel. Following the re-occurrence of Eostichomitra carnegiense and Amphiternis aff. stocki (Campbell \& Clark) as well as roughly coinciding with the FAD of Eostichomitra communis (Squinabol), this fauna is characterized by few robust forms, including the Eostichomitrids, A.aff stocki and 
Diacanthocapsa aff. granti (Squinabol), as well as the re-establishment of benthos through the presence of benthic foraminifers (fig. 10).

Within the D. multicostata Zone, the Crucella messinae Subzone is marked by the FAD of Crucella messinae Pessagno. Similar to the X. spicularis Subzone, this short lived radiation is found only at the beginning of the Campanian. The Campanian FAD of this species in the Sverdrup Basin differs from the late Cenomanian FAD noted by other authors (fig. 9).

\subsubsection{Macrofossils}

Macrofossils taken from the uppermost portion of the measured Kanguk Formation ( $475 \mathrm{~m}$ from the Hassel-Kanguk contact at Hoodoo Dome), were submitted to James Haggart at the Geological Survey of Canada, Vancouver. Fossil specimens were identified as Sphenoceramus patootensis (de Loriol). This sphenoceramid is widespread throughout the Pacific Boreal and Siberian provinces (Amon \& De Wever, 1994;

Vishnevskaya \& De Wever 1998) confining these strata to late Santonian to early Campanian (Jeletzky, 1968, 1970; Haggart, 2011). 


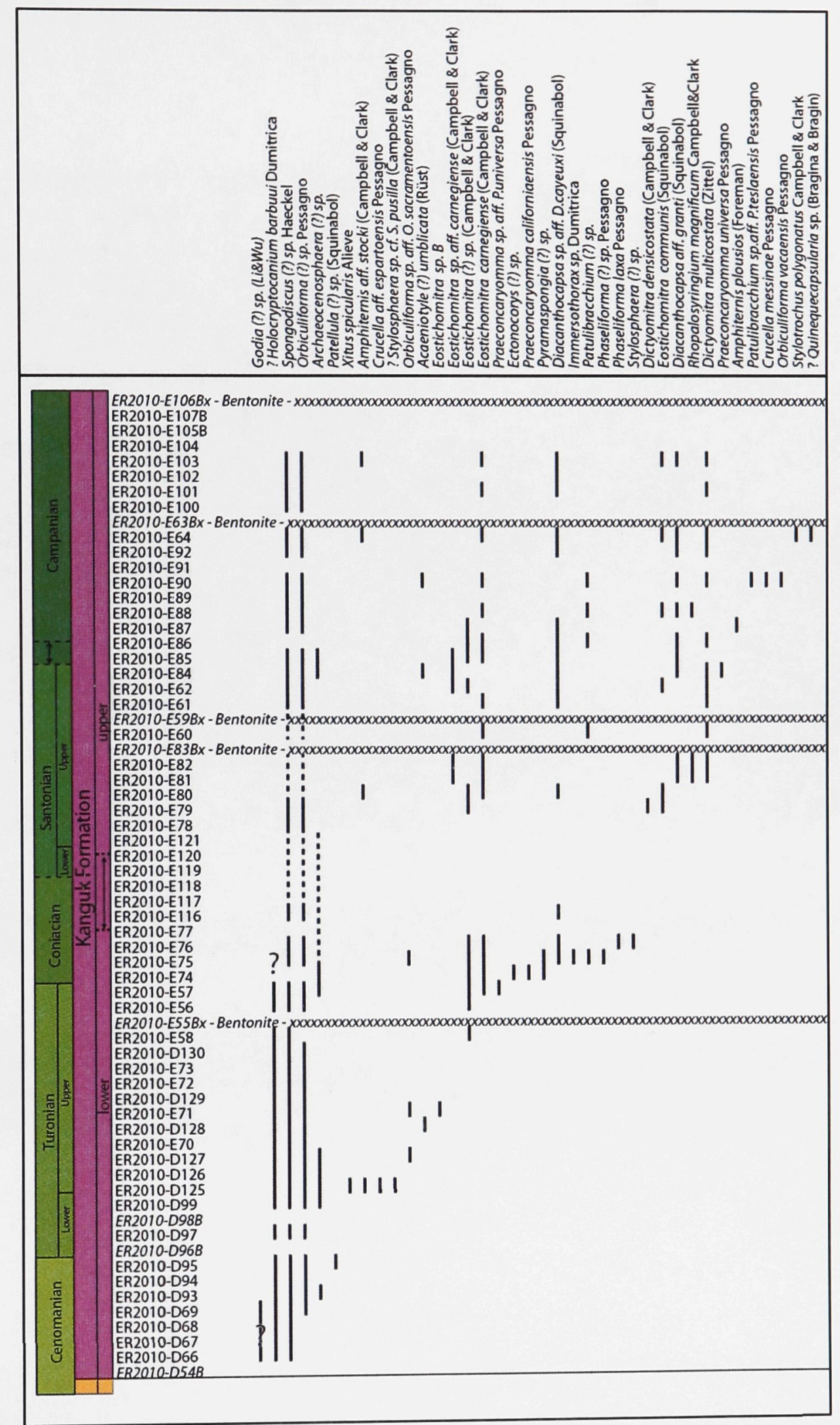

Figure 8: Range chart of radiolarian taxa. Samples listed in order of their first appearances within the section, with the base of the range chart corresponding to the Hassel-Kanguk contact. B's listed beside sample numbers denote barren samples. 


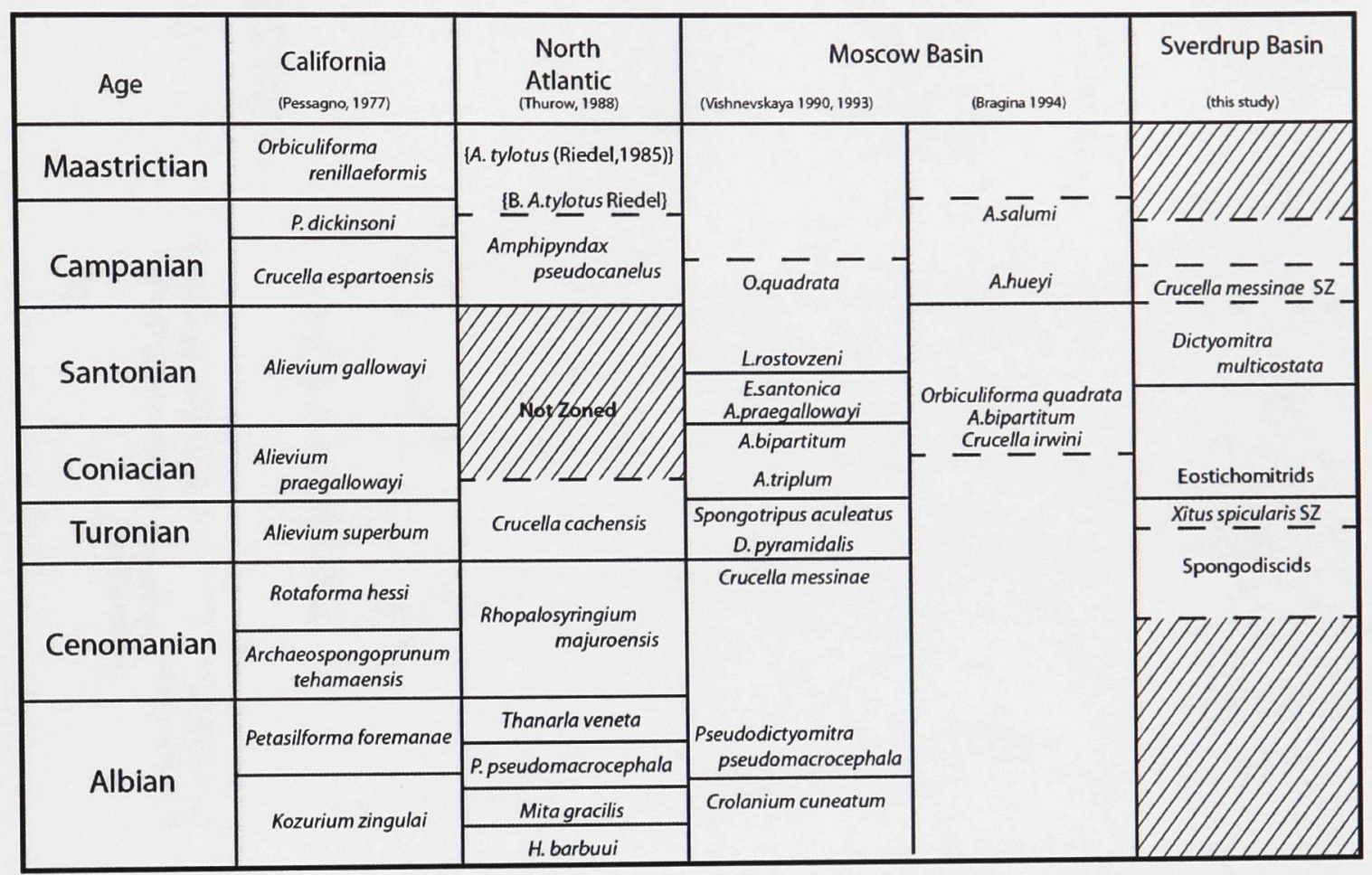

Figure 9: Correlation chart of radiolarian zones from California, the North Atlantic Ocean, the Moscow Basin and the zonation proposed from this study in the Sverdrup Basin.

Figure 10 (next page): Compilation of Kanguk Formation analysis showing clastic input proxies $\% \mathrm{Al}, \mathrm{Ti} / \mathrm{Al}$, Mo and \%S, Total Organic Carbon (\%wt), Hydrogen Index, percent ratio of spumellarian:nassellarian content, radiolarian preservation and abundance curves (after Baumgartner, 1992). Radiolarian and notable events and OAE's are superimposed. 


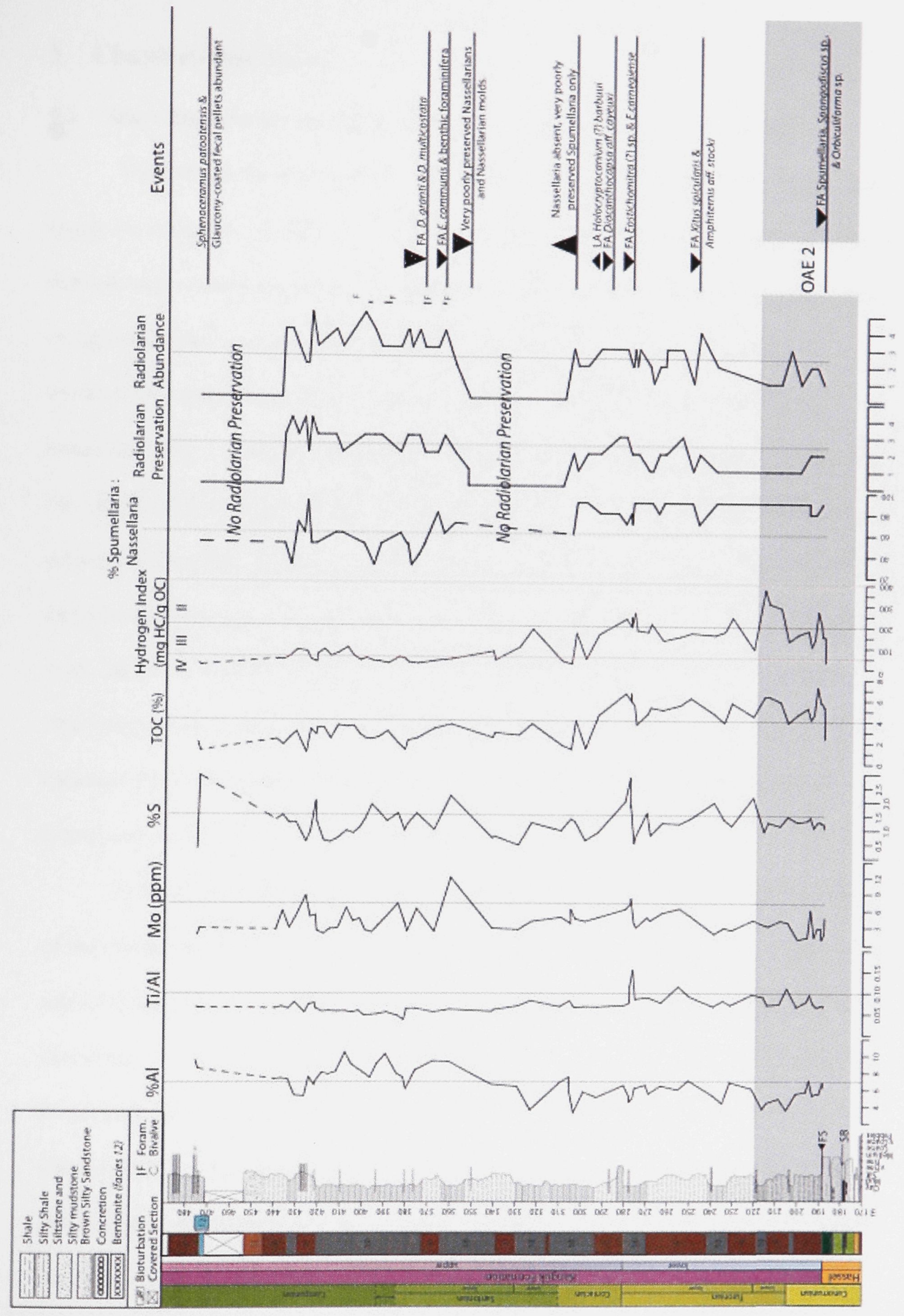




\section{Chapter: Discussion}

\subsection{Stage Boundaries and Radiolarian Biostratigraphy in the Boreal Sea}

Until this study, the Kanguk Formation has remained undivided although it spans nearly the entire late Cretaceous. Here, a new stratigraphic framework with tentatively defined stage boundaries for this lithologically monotonous formation is proposed based on an integrated biostratigraphic and chemostratigraphic approach. In addition, correlation to the global sea-level curve of Kominz et al. (2008) has refined those boundaries (fig. 11). Within the Hoodoo Dome measured section, the Hassel Formation did not provide pelagic fauna for analysis, due to its coarse-grained texture and shallow depositional settings, however, recent studies have reinforced the Late Albian through mid-Cenomanian age of the Hassel Formation through palynological evidence (Galloway et al., 2012). In contrast, the deep water settings of the Kanguk Formation preserved a rich pelagic fauna, allowing for the subdivision of the formation into three zones, and two subzones based on radiolaria. In order to place this new zonation into a stratigraphic framework, criteria for each stage boundary are discussed.

A latest Cenomanian age for the base of the Kanguk Formation and the position of the middle Turonian is confirmed by the positive excursion in the $\delta{ }^{13} \mathrm{C}_{\text {org }}$ isotope curve and its interpretation as OAE 2 (Jens Herrle, pers. comm.). This record will be published elsewhere. The Kanguk Formation can be divided into two informal members based on its geochemical signature. The lower member shows a prominence in Type II (Planktonic) kerogen, with an increased preservation of organic carbon at $\sim 6 \%$ throughout the basal portion. The upper member shows a dominance of Type III (Humic) kerogen, and TOC values drop to $\sim 3 \%$. This change from distal marine to increasingly 


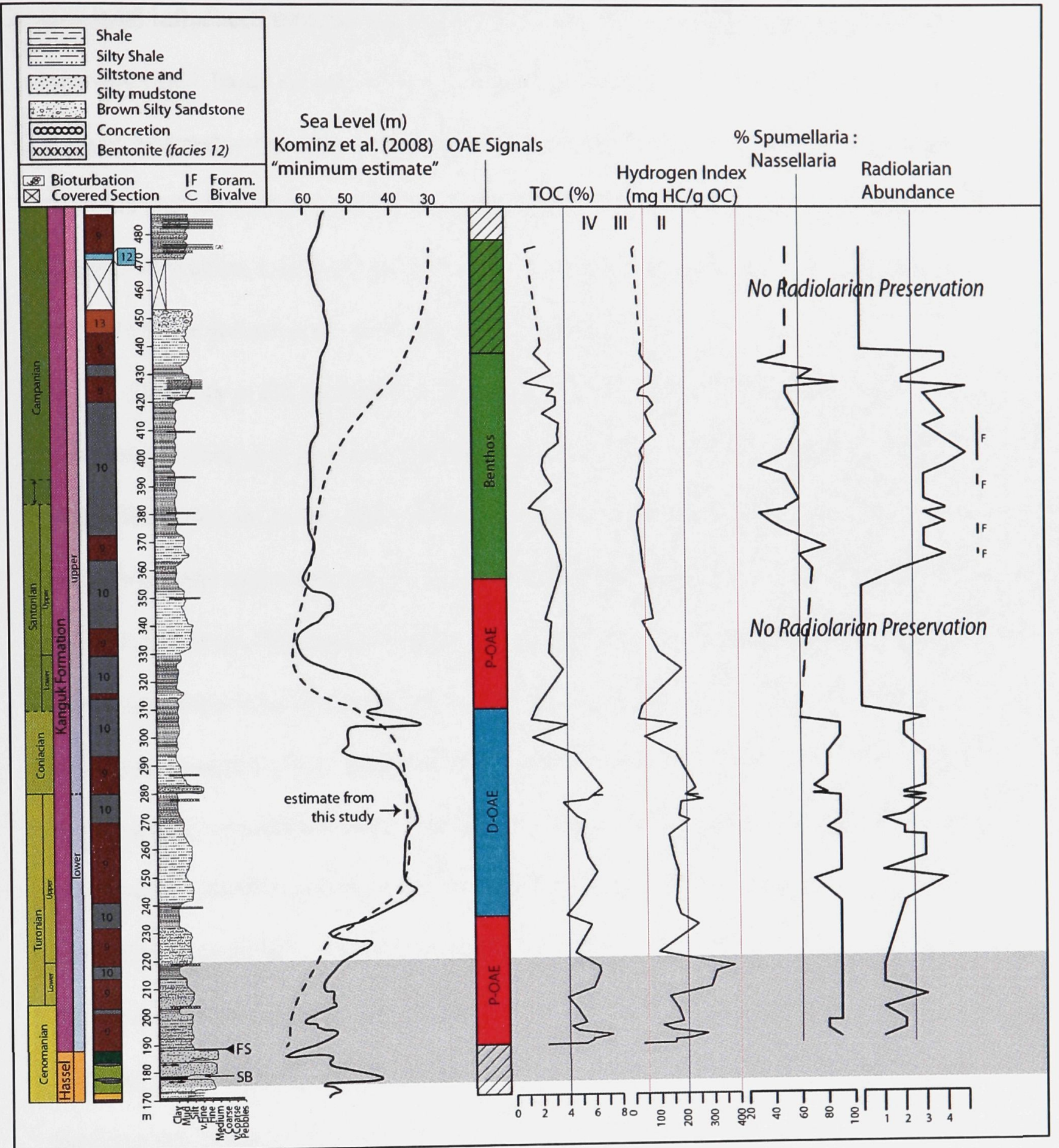

Figure 11: Compilation of stratigraphy from the Kanguk Formation, Atlantic sea level curve from Kominz et al. (2008) and estimate from this study, OAE signals, Rock Eval and radiolarian data. OAE signals were calculated from these data, as described in the text. 
terrestrial influenced environments has been noted also by Núñez-Betelu et al. (1994) who described, based on palynology and Rock-Eval results, the lower portion of the Kanguk Formation from Axel Heiberg and Ellesmere islands as possessing petroleum potential and high counts of marine palynomorphs. In contrast, their upper portion of the Kanguk Formation was characterized by the return to terrestrial species, which they attribute to the initiation of renewed deltaic sedimentation.

Similarly to the palynofloras, the pelagic system recorded by radiolarian assemblages change at that chemical boundary. The lower member is dominated by Spumellaria that are poorly preserved and variable in abundance, whereas at the boundary to the upper member an increase in both the preservation and abundance of Nassellaria occurs. The faunal change and radiation is possibly controlled by sea level. This assumption is based on models presented by Erbacher et al. (1996) who used radiolarian assemblages in black organic-rich shales to propose two depositional models. A transgressive period and maximum flooding phase with nutrient enrichment leads to a low-diversity, shallow dwelling radiolarian assemblage controlled by a thick Oxygen Minimum Zone (OMZ). During regressive periods and lowstand phases, increasing amounts of detritic organic matter leads to a minor OMZ lower in the water column allowing for increased radiolarian diversities and radiations of deeper dwelling taxa. In applying this model to the Kanguk Formation the lower portion is marked by oceanic anoxia through increased productivity (P-OAE's) occurring during times of transgression and maximum flooding. Increased productivity coupled to increased nutrient leaching caused the elevated consumption of oxygen within the water column and thus the upward ingression of the OMZ. Paired with this upward migration, reduction in the deep water 
pelagic and benthic fauna (e.g. lack of benthic foraminifera) and decrease in species diversity, restriction of the population size based on availability and location of nutrients, are a few of the effects, together with an increased preservation of type II (marine) organic matter within sediments. Corresponding with the spongidiscids assemblage zone (fig. 9), deep-water taxa could not survive due to the increased productivity of spongy Spumellaria within the upper portions of the water column. This zone is suspected to correspond with the basal assemblage put forward by Vishnevskaya and De Wever (1998) representing the Albian through Cenomanian of the Russian platform equally dominated by Spumellaria and spongy fauna. Application of the second model of Erbacher et al. (1996) to the Kanguk Formation would propose that the radiation of the Nassellaria above the boundary between the two members would signal a regressive event.

In order to use this faunal change in radiolarian composition I make a comparison with the sea-level curve for the North Atlantic Ocean (fig. 11; Kominz et al., 2008). There, the mid Turonian to early Coniacian is marked by a time of regression and lowstand, also recognized in the Western Interior Sea (Schröder-Adams et al., 2012). This combined with the radiolarian radiation and a lithology change to a siltier interval forms the basis of a tentative placement of the Turonian/Coniacian stage boundary. The latest Turonian and earliest Coniacian is then marked by an increase in abundance of radiolaria and the first appearance of a few Tethyan forms, namely X. spicularis and A. aff. stocki. Few eostichomitrids (Eostichomitra sp. $B$ and $E$. aff. carnegiense) appear here as well, however, their general lack of preservation makes identification to species level difficult. This minor radiation is suggested to occur due to the depression of the OMZ 
during regression, initiating a D-OAE as proposed by Erbacher et al. (1996). Here, increased radiolarian diversity is linked to the rejuvenation of deeper water ecozones, with continued bottom water anoxicity supported by the lack of benthos. Further, this radiation coincides with a similar radiation in the Moscow Basin (Vishnevskaya \& De Wever, 1998). Within the Sverdrup Basin, key first appearances marking the beginning of this radiation include Eostichomitra carnegiense. This species is known from the Santonian of the Russian Platform (Popova-Goll et al., 2005) and stratigraphically higher still from the Czech Republic (Bak, 1999) and New Zealand (Hollis et al., 2003). Amphiternis aff. stocki, also appearing in the Turonian, is found in the Santonian of the Moscow Basin (Vishnevskaya \& De Wever, 1998), but otherwise can range as far down as the Turonian and Cenomanian by other authors from Tethyan localities such as Italy and Greece (Musavu-Moussavou et al., 2007; Bandini et al., 2006; O’Dogherty, 1994). Further, Diacanthocapsa aff. cayeuxi appears as early as the mid Coniacian, where other authors have attributed its occurrence strictly to the Campanian, notably from the Pacific (Table 2; Empson-Morin, 1981).

Moving up through the Coniacian, sea-level rise is indicated by an increase in marine derived organic matter as seen in the HI values corresponding to a fine-grained shale lithology starting just below $300 \mathrm{~m}$ in the measured section (fig. 11). The return to higher sea-levels within the Santonian sees a return to poorly preserved Spumellaria assemblages. At the onset of transgression during the mid-Coniacian, and through to highstand during the Santonian, sedimentation rates decrease but the leaching of nutrients from coastal lowlands, which are being flooded, initiates an increase in productivity. With this, the cycle of an increased OMZ repeats itself. 
The Coniacian/Santonian boundary is placed where the shift occurs to decreased TOC and HI values suggesting Type III/IV (Humic) kerogen (figs. 6, 10, 11). Sparse benthic foraminiferal occurrences within the Santonian suggest increasingly oxygenated bottom water conditions inhibiting increased carbon burial. The upper Santonian is marked by an increase of nassellarian species, population and preservation, with the first appearance of Eostichomitra sp. as well as the FAD of Dictyomitra multicostata. The upper Santonian signals return to lower sea levels.

The Santonian/Campanian boundary is defined by diatoms using the Arctic zonation by Tarpia and Harwood (2002) (Murray Hay, pers.comm.). The uppermost Kanguk Formation is constrained by the occurrence of Sphenoceramus patootensis (de Loriol), as mentioned in Chapter 4.3.2, which correlates across the Boreal Realm, found throughout the Pacific Boreal and Siberian provinces (Amon \& De Wever, 1994; Vishnevskaya \& De Wever, 1998) confining these strata to late Santonian to early Campanian in age (Jeletzky, 1968, 1970; Haggart, 2011).

Stage boundaries presented here for the Kanguk Formation of the Sverdrup Basin are tentative (fig. 9). Additional geochronology from the bentonites will allow refinement of this proposed stratigraphic framework.

Within the Russian Platform, radiolarian biostratigraphy from the Moscow Basin and studies of the relationships between Nassellaria and spongy Spumellaria reveal possible basin depth and latitude, using their relative abundance. Forms with long and thin spines, are attributed to deep basins with slow sedimentation rates, where shallower basins would possess greater spongy tests and an increase in thick-walled species, further aiding characterization and comparison of assemblages for distal, deep and cold regimes 
to those of shallower, though still cold basins (Vishnevskaya \& De Wever, 1998;

Vishnevskaya et al., 1999; Vishnevskaya et al., 2009; Filatova \& Vishnevskaya, 1997).

Tethyan faunal influences could be more pronounced in the Moscow Basin as compared with the Sverdrup Basin due to its geographic position. The lack of prominent Tethyan influences such as Dictyomitra ferosia, Dictyomitra maleolla, Dictyomitra lilyae, and Xitus spicularis, as well as Alievium superbum and Patellula planoconvexa as found within the Moscow Basin during the Albian to Turonian and Campanian-Santonian intervals, respectively (Vishnevskaya \& De Wever, 1998), indicates that the Boreal Sea was isolated from these migration routes up to the latest Turonian. The rare occurrence of $X$. spicularis is of interest, however, as it too appears roughly coeval namely during the Turonian to that of the Moscow Basin. Its range is much shorter in the Boreal Sea compared to the Moscow Basin, where it is noted to extend from the Albian through Turonian. This suggests that during the Turonian, a connection between the Moscow Basin and the Sverdrup could have existed, likely through the opening North Atlantic (Torsvik et al., 2002) and the early Turonian highstand.

Within the North Atlantic, robust radiolarian species were used for the establishment of a mid to late Cretaceous. Although many of the zonal marker species were not found within the Boreal setting (this study), similarities exist a on generic level. This in turn could represent a similarity in basin conditions, highlighting key environmental signals through radiation events, further correlating with anoxia (Erbacher, 1998; Erbacher et al., 1996; Erbacher \& Thurow, 1998). The middle Californian Cretaceous of the Pacific west coast of North America represents one of the closest localities with described rich radiolarian fauna and good preservation of transitional 
Boreal and Tethyan species (Campbell \& Clark, 1944; Pessagno, 1976). Although endemism may play a role in the species abundances and presence/absence of specific species (Erbacher, 1998), cosmopolitan and robust species should correlate well between regions (Campbell \& Clark, 1944). Radiolarian descriptions and taxonomy from the Corral Hollow shales, part of the Moreno Grande Formation, sampled from limestone nodules from the late Campanian (Pessagno, 1976), aided the description of samples found in the Boreal setting, though no range chart nor zonation were provided.

Bandini et al. (2006) preface their study on the Turonian radiolaria from Karnezeika (Greece) with the fact that Upper Cretaceous radiolaria are restricted to times of high silica productivity in pelagic environments due to ongoing tectonic activity. The Kanguk Formation has numerous bentonites and the original ash deposits could have aided the preservation of siliceous assemblages including radiolarian and diatoms. In fact, shales surrounding bentonites within the Kanguk Formation display increased preservation and increasing diversity around their deposition. It is speculated that the preservation of Cretaceous siliceous microfossils on Ellef Ringnes Island is enhanced by the process of salt doming having ultimately prevented deep burial that would have resulted in dissolution and possible replacement. 


\begin{tabular}{|l|l|l|l|l|l|l|l|}
\hline Species & This Study & $\begin{array}{l}\text { Pessagno } \\
\mathbf{( 1 9 7 6 )}\end{array}$ & $\begin{array}{l}\text { Hollis \& } \\
\text { Kimura } \\
\mathbf{( 2 0 0 1 )}\end{array}$ & $\begin{array}{l}\text { Erbacher } \\
\mathbf{( 1 9 9 8 )}\end{array}$ & $\begin{array}{l}\text { Popova- } \\
\text { Goll et al. } \\
\mathbf{( 2 0 0 5 )}\end{array}$ & $\begin{array}{l}\text { Vishnevskaya \& } \\
\text { De Wever } \\
\mathbf{( 1 9 9 8 )}\end{array}$ & $\begin{array}{l}\text { Empson- } \\
\text { Morin } \\
\mathbf{( 1 9 8 1 )}\end{array}$ \\
\hline $\begin{array}{l}\text { Diacanthocapsa } \\
\text { cayeuxi }\end{array}$ & Con - Camp+ & $\begin{array}{l}\text { Camp- } \\
\text { Maas* }\end{array}$ & n/a & n/a & n/a & n/a & Camp \\
\hline $\begin{array}{l}\text { Dictyomitra } \\
\text { multicostata }\end{array}$ & Sant-Camp+ & Camp- Maas & $\begin{array}{l}\text { L.Camp- } \\
\text { E.Maas }\end{array}$ & L.Tur-Sant & Sant-Camp & Con- L.Camp & n/a \\
\hline $\begin{array}{l}\text { Eostichomitra } \\
\text { carnegiense }\end{array}$ & $\begin{array}{l}\text { (Tur?)Con- } \\
\text { Camp+ }\end{array}$ & Camp- Maas* & $\begin{array}{l}\text { L.Camp- } \\
\text { E.Maas }\end{array}$ & n/a & Sant & n/a & n/a \\
\hline $\begin{array}{l}\text { E. communis } \\
\text { (Con?)Sant- }\end{array}$ & $\begin{array}{l}\text { Camp- } \\
\text { Camp+ }\end{array}$ & $\begin{array}{l}\text { Mlb-Tur } \\
\text { (Con?) }\end{array}$ & L.Alb-L.Ceno & Camp & E.Con- L.Sant & n/a \\
\hline $\begin{array}{l}\text { A. aff. stocki } \\
\text { (Tur?)Sant- } \\
\text { Camp+ }\end{array}$ & Camp-Maas* & $\begin{array}{l}\text { Cen-Maas } \\
\text { Xitus spicularis }\end{array}$ & Tur & L.Alb-Sant & Sant & Alb-Maas & n/a \\
\hline
\end{tabular}

Table 2: Summary table comparing ranges of diagnostic and robust species of Nassellaria from this study to those of other authors. In order from left following this study: California Coast Ranges, Japan, Equatorial Atlantic, the Russian Platform, Moscow Basin, and Mid-Pacific. (Alb = Albian, Tur $=$ Turonian, Con $=$ Coniacian, Sant $=$ Santonian, Camp $=$ Campanian, + denotes uncertain but could extend further, * from Campbell and Clark, 1944).

\subsection{Influence of Bentonites on the Marine System}

Geochemical responses during times of increased volcanism may also be responsible for increased test preservation (Bandini et al., 2006). Using major element geochemistry from the Kanguk Formation (fig. 10), clastic-input proxies of Al and Ti, used for provenance studies of fine-grained sediments (Ver Straeten et al., 2011), show distinct peaks associated with volcanism and bentonite deposition (fig. 10). The relative immobility of $\mathrm{Al}$ and Ti during weathering and diagenesis allow for their use as a valuable proxy, where $\mathrm{Al}$ is a key constituent of many clay minerals, and Ti more abundant in mafic minerals such as biotite and generally attributed to the coarser component of fine-fractions (Bertrand et al., 1994; Young \& Nesbitt, 1998). As the geochemical data was acquired by way of ICP-MS, Si and LOI values were not measured, nor were the elemental analyses given in oxides. Thus, attempting calculation of $\mathrm{Si}$ returns the combination of $\mathrm{Si}$ and volatiles $\left(\mathrm{CO}_{2}\right.$ and $\left.\mathrm{H}_{2} \mathrm{O}\right)$, the effects of which 
should not be discounted as in shales LOI can amount up to 20\% (Young \& Nesbitt, 1998). A key correlation that can be made includes Si-dilution effects near ash beds. Settling silica-rich ash debris through the water column is illustrated by negative peaks in $\% \mathrm{Al}$ corresponding with a dilution effect.

Occasionally, bentonite deposition corresponds with delayed peaks in Mo and S, suggesting that pore-fluids after deposition could have been enriched in sulfides and metals. Further, these occasionally coincide with peaks in TOC (\%). This suggests that much of the burial of carbon and its preservation can be linked to increased sedimentation rates, and thus rapid burial. Other peaks of TOC that correlate with increases in the abundance of radiolaria may suggest organic carbon preservation by productivity, elevating the oxygen minimum zone (OMZ).

Further correlations were attempted between the element Mo and TOC (\%), as covariation is suggested to exist within euxinic and possibly anoxic intervals (Scott \& Lyons, 2012; Ver Straeten et al., 2011; Young \& Nesbitt, 1998; Sageman et al., 2003). The relationship between Mo and TOC displays a weak correlation within the Kanguk Formation, notably nearest the contact between the Hassel and Kanguk formations. Here, TOC shows increased organic carbon preservation of up to $8 \%$, nearly the maximum preservation throughout the entire Kanguk section, and Mo shows a delayed minor excursion. Further up section, the maximum preservation of Mo $(\sim 12 \mathrm{ppm})$ is found at the same level as a large spike in $\% \mathrm{~S}$, where a minor variation is found in the TOC. These few correlations are possibly illustrating decreased preservation of organics due to acidic $\left(\mathrm{H}_{2} \mathrm{~S}\right)$ pore-fluids. Further, Mo shows values less than $25 \mathrm{ppm}$ throughout the entirety of the section, though rarely less than 2 ppm (the continental average; Scott \& 
Lyons, 2012), which illustrate that ocean surface conditions could have been enriched in sulfide rich pore fluids, the environment would not likely have been euxinic (Scott \& Lyons, 2012).

\subsection{Sequence Stratigraphy of the late Cretaceous from Hoodoo Dome: Integration with the current Sequence Stratigraphic Model}

The Hoodoo Dome measured section adds valuable data for correlation within the Sverdrup Basin. This central basin section displays a transition from progradational deltaic/ nearshore environments, through distal-shelf deposition during times of reduced benthic life, and possible long-term bottom water anoxia. As this is a single section, a sequence stratigraphic model cannot be feasibly created, however, combining this with the standing sequence stratigraphic framework for the Sverdrup Basin (Embry \& Beauchamp, 2008), few refinements can be noted.

The measured section extends from the upper Albian Christopher Formation which shows a gradational contact with the overlying Hassel Formation sandstones recording the regressive systems tract (RST). Falling sea levels crossing the AlbianCenomanian boundary and reduced basin subsidence allowed for the progradation of coarser clastics, and the coarsening upward succession into basal Hassel Formation (Kominz et al., 2008; Embry \& Beauchamp, 2008).

The Hassel Formation from Hoodoo Dome clearly represents several distinct boundaries defining parasequences. The basal portion of the Hassel Formation grades and forms the latter half of the RST that began within the Albian Christopher Formation. A plant-rich ferruginous silty sandstone layer marks the transition from the underlying 
marine sandy mudstones to interbedded parallel and flaser bedded sands. Base level fall continued, with further increase in the volume of sand, through nearshore settings into foreshore and ultimately into a non-marine setting as indicated by coals. Plant material and grey clay horizons indicative of lacustrine environments, supported by type III/IV organic matter, characterize the end of base level fall within the upper portion of the Hassel Formation. A few pebble lags found in ferruginous beds indicate erosional horizons either through sea-level inundations or movement of channels within the shoreface to backshore environments. The lack of indicative fossils in this marginal marine to terrestrial environment does not allow the direct correlation to the Albian/Cenomanian breakup unconformity as postulated by Embry and Dixon (1990) and Embry and Beauchamp (2008). Further north in the Sverdrup, on Axel Heiberg Island, the intercalation of Strand Fiord Formation volcanics with the Bastion Ridge Formation, correlative to the upper-most Hassel Formation, is dated to $95.3 \pm 0.2$ Ma corresponding to the mid-Cenomanian, and caps T-R 3 which began in the latest Aptian-early Albian with the deposition of the Christopher Formation (Trettin \& Parrish, 1987; Embry \& Osadetz, 1988; Embry \& Beauchamp, 2008).

The mid-Cenomanian is also a time of rapid sea level rise, which, paired with subsidence caused by the continued opening of the Amerasian Basin, marks the onset of the Kanguk Formation deposition, sharply overlying the Hassel Formation (figs. 5 F,G; Embry \& Beauchamp, 2008; Kominz et al., 2008). The sequence boundary, which marks this onset of transgression, is found within the Hassel Formation and is placed at the final coal bed (at $178 \mathrm{~m})$ within the upper portion of the section. This thick coal bed $(\sim 50 \mathrm{~cm}$ thick) is the division between terrestrial and marine environments, where flooding of this 
coal represents shoreline inundation and the return to marine sedimentary processes (Bhattacharya \& Walker, 1991).

The Kanguk Formation represents the initiation of a new T-R cycle within the Sverdrup Basin (T-R 4 as defined by Embry \& Osadetz, 1988). Though condensation is intrinsic to shale basins, great variability in geochemistry and micropaleontology are preserved within this unit. As discussed above, two informal units divide the Kanguk Formation, corresponding to differing forms of bottom water anoxia, highlighting parasequences. The lower Kanguk Formation has been shown to reflect a TST, supported with biofacies due to over-productive surface waters closing benthic ecosystems and deeper waters by the increased uptake of oxygen and ingression of the OMZ (Erbacher et al., 1996). This can also be seen in increased TOC preservation and high HI values, corresponding to the OAE 2 signal (J. Herrle, pers.comm.), the Cenomanian-Turonian Boundary Event. The middle Turonian (Kominz et al., 2008) regression is accompanied by a minor radiolarian radiation (fig. 8), corresponding to increased detritus driven anoxia (D-OAE) lasting until the earliest Coniacian and ending the first parasequence. During the middle Coniacian transgression is highlighted by an extinction of many Nassallaria, and the persistence of only a few poorly preserved Spumellaria.

Further variations and cyclicity related to sea-level changes reflected within this condensed section have been shown moving through the Coniacian-Santonian (see section 5.1). This marks the transition to the overarching RST within the T-R cycle, as previously defined (Embry \& Osadetz, 1988). Generally, terrestrial kerogens (type III, and IV) and decreasing preservation of organic matter characterize the upper Kanguk Formation, as also previously noted by Núñez-Betelu et al. (1994). Increasing diversity in 
radiolaria suggests that regression depressed the $\mathrm{OMZ}$ allowing for deeper water fauna to infiltrate the basin again. During mid to late Santonian, the benthos is under restoration, with rare beds preserving benthic foraminifera. The uppermost section of the measured Kanguk Formation preserves coprolites and glauconite pellets (figs. 6, 10). Increase in pelagic detritus in form of glauconite pellets (green sands) and wood debris found within upper Kungak strata on Devon Island, was interpreted as a return to terrestrial dominated sedimentation and approaching shoreline (Chin et al., 2008).

Finally, although not measured at the Hoodoo Dome section, the Expedition Formation overlies the Kanguk and is interpreted, similarly to the Hassel Formation overlying the Christopher, to be a deltaic to nearshore depositional environment, continuing the RST to the end of the T-R 4 cycle (Embry \& Osadetz, 1988; Embry \& Beauchamp, 2008; Chin et al., 2008).

\subsection{Paleoenvironmental change and paleogeographic implications in the Boreal}

Sea

The newly established Boreal radiolarian assemblages and their biostratigraphic occurrences can now be compared with existing paleogeographic reconstructions for the Boreal Realm. Maps by Scotese (http://www.scotese.com), Blakey

(http://www.cpgeosystems.com), and ODSN (http://www.odsn.de) document the various stages of openings of the North Atlantic, the North Pacific Gateway, and the CWIS and their connections to the Boreal Sea. These can be related to postulated faunal migrations.

To my knowledge the proposed radiolarian zonation is the first for Arctic Cretaceous strata; other zonations and radiolarian studies of Boreal faunas that were 


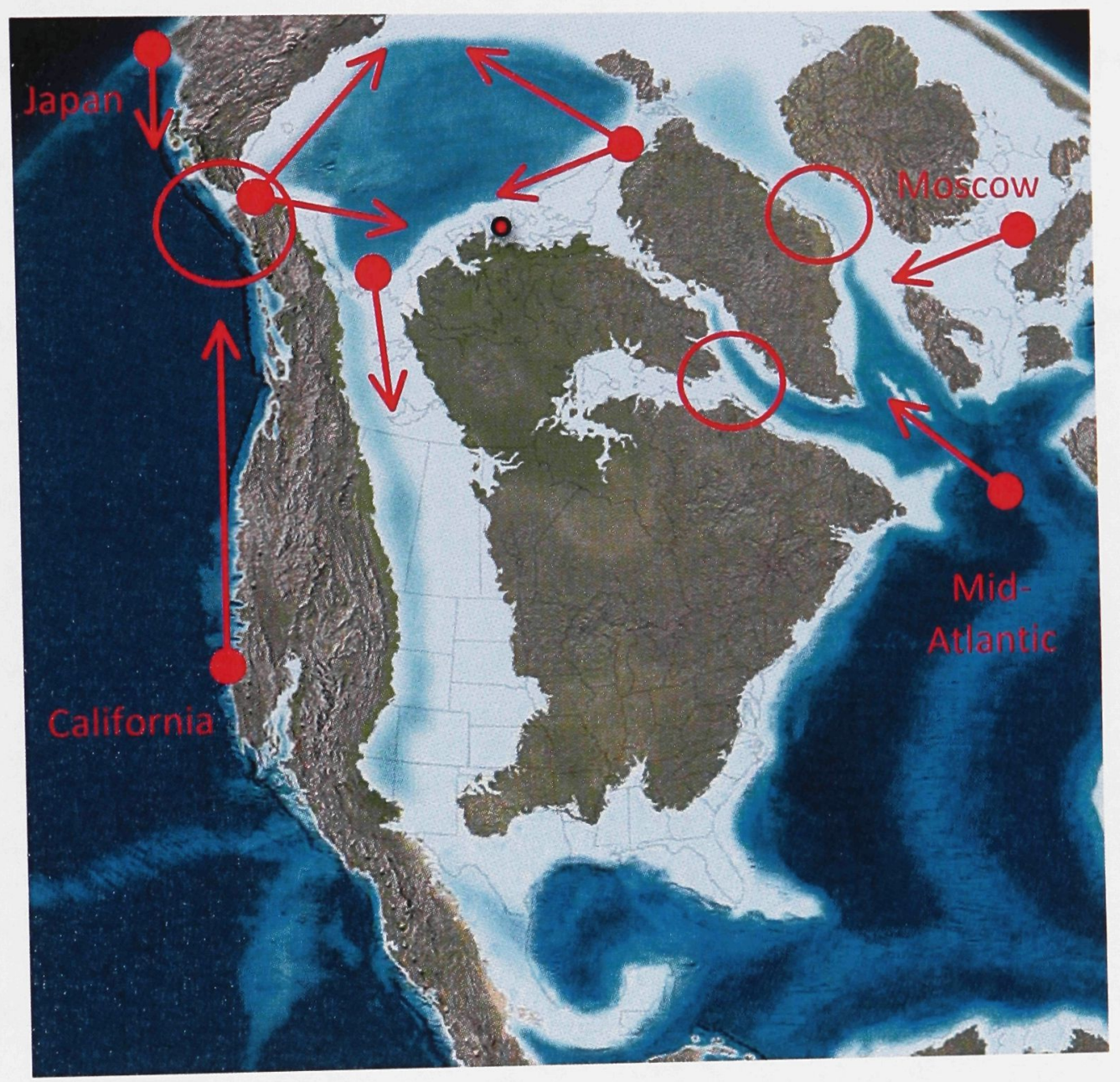

Figure 12: Paleogeographic reconstruction for the Santonian (85 Ma) by Blakey (2011) showing possible migratory routes and gateways with respect to the locations of other study areas, as noted within the text. 
available for comparison were all located outside of the polar latitudes, as plotted within paleogeographic reconstructions (Pessagno, 1976; Vishnevskaya, 1986; Vishnevskaya et al., 2006; Vishnevskaya \& De Wever, 1998; Filatova \& Vishnevskaya, 1997; Campbell \& Clark, 1944; Thurow, 1988; Erbacher \& Thurow, 1998; Erbacher et al., 1996; Hollis \& Kimura, 2001; Empson-Morin, 1981; Foreman, 1971, 1975, 1978; authors from discretely Tethyan regions have been omitted). Comparison between assemblages studied here with assemblages of these authors (see Table 2; figs. 9, 12) identify greatest resemblance with those from coastal Pacific regions as described from the Campanian to Maastrichtian by Campbell \& Clark (1944) and Pessagno (1976), although those are better preserved. Hollis and Kimura (2001) addressing radiolarian assemblages form Japan, extend the ranges of species such as Xitus spicularis, Amphiternis aff. stocki (=Amphipyndax stocki), Eostichomitra carnegiense (=Stichomitra carnegiense) and Eostichomitra communis (=Stichomitra communis) further down, with the furthest into the Albian/Cenomanian (table 2). These similarities between the North Asian Pacific and Boreal Sea suggest possible connectivity between the Pacific Ocean and Boreal Sea, likely reinforced by connection through the Asian-Alaskan Seaway (AAS) during the late Cretaceous (fig. 12). Similarly, faunal similarities to the Moscow Basin (Vishnevskaya, 1986; Vishnevskaya et al., 2006; Vishnevskaya \& De Wever, 1998; Filatova \& Vishnevskaya, 1997), indicate North Atlantic marine connections. Considering the proximity that the Moscow Basin has with the Equatorial Atlantic (Erbacher, 1998), this may suggest the concurrent upward migration of fauna from the Tethys through the Equatorial Atlantic to the Eurasian basins (Moscow Basin included), as well as the Northward migration through the North Pacific (fig. 12). 
Current paleogeographic maps show differences in the Boreal setting and their connecting pathways. Upper Cretaceous maps from Ron Blakey (2011) show numerous epeiric and shallow seas through the Atlantic and Eurasian regions, a fully connected WIS showing the Hudson Straight during the Campanian ( $85 \mathrm{Ma}$ ), as well as a restricted opening into the North Pacific to the Boreal Sea (fig. 12). Scotese (2002) shows similar reconstructions for the mid-Cenomanian (94 Ma) suggesting marine connections between the Boreal Sea and the surrounding oceans. Further, maps constructed with the ODSN models show far fewer connections. Based on their reconstructions possible faunal migrations routes would include the Alaska-Asian gateway and the WIS. The scarcity of radiolarian assemblages within the CWIS (e.g. Wall, 1975) partly due to its shallow bathymetry, would suggest that the main radiolarian faunal dispersal took place through the Pacific and AAS, and the Eurasian, Tethyan and Atlantic realms.

The Cenomanian - Turonian Boundary Event has been thoroughly studied around the world, and attributed to global anoxia (OAE 2) (e.g. Leckie et al., 1992). The OAE 2 correlates with times of highest global temperatures during the mid-Cretaceous climate maximum, extending from the mid-Cenomanian to the mid-Turonian (Friedrich et al., 2012). The Boreal setting as documented here clearly records this event (corroborated by $\delta^{13} \mathrm{C}_{\text {org }}, \mathrm{J}$. Herrle, pers.comm.), and other paleoenvironmental changes such as variation in the OMZ as driven by productivity. The OAE 2 is well documented in the WIS (e.g. Arthur \& Sageman, 2005; Schröder-Adams et al., 2012) and is now extended into the Boreal Sea. Unique to the study area is the late reoccurrence of benthic fauna falling into the Santonian/Campanian. Compared to various localities in the WIS the timing of bottom water oxygenation varies as documented by diachronous reoccurrence of benthic 
foraminifera (e.g. Thomson et al., 2011; Schröder-Adams et al., 2012). Further study of biogeographic provinces related to the opening and closing of marine pathways and varying productivity levels is needed. 


\section{Chapter: Conclusions}

A lithostratigraphic, micropaleontological and geochemical study of the late Albian to Campanian Christopher, Hassel and Kanguk formations as exposed near Hoodoo Dome on Ellef Ringnes Island resulted in the following conclusions:

1) Sea-level controlled lithologies are subdivided into a total of 13 facies. These are distinguished through lithology, paleontological and ichnofossil content, and geochemistry. The progression of these facies identifies a prodelta to deltafront/shoreface and terrestrial environments to distal offshore settings.

2) Throughout the nearly unlithified Hassel Formation lithological change is gradational with shallowing and increasing sediment input. A sequence boundary is placed at the top of the last substantial coal bed within the uppermost Hassel Formation. The overlying sands of the Hassel Formation are genetically related to the rapid transgression as manifested in the shales of the Kanguk Formation.

3) A combination of microfossil occurrences, geochemistry, carbon isotope signals, productivity models and global sea-level history has been used to propose the first subdivision of the Kanguk Formation into stages.

4) The silica-dominated microfauna dictated the proposal of a first radiolarian zonation for the Cretaceous Boreal Sea as found in the Sverdrup Basin. Three zones and two subzones are initially proposed for the Kanguk Formation.

5) A dominance of Spumellaria is correlated to transgressive phases with an expanded OMZ. Radiations in Nassellaria correspond to regressive and lowstand phases with a depressed OMZ. Both phases are coupled with anoxic bottom conditions due to increased surface productivity resulting in the lack of benthos. An exception is formed by the 
Santonian, where a sparse benthic foraminiferal assemblage and the eventual occurrence of Sphenoceramus hints at increasing oxygen concentrations on the sea floor.

6) Paleobiogeographic analysis of radiolarian assemblages in comparison to existing paleogeographic maps suggest faunal dispersal through the Alaskan-Asian Seaway from the North Pacific and through the initial narrow North Atlantic basins from Eurasian and Tethyan sources.

Future study will add geochronological analysis of bentonites within the Kanguk Formation testing the newly proposed stage boundaries of this formation. Additional microfossil studies including dinoflagellate, diatom and silicoflagellate assemblages will test the productivity model as proposed here. New localities that preserve the siliceous pelagic component will further refine the radiolarian zonation as illustrated here. 
Radiolarian Plates 
Plate 1: Kanguk Formation Spumellaria

1. Spongodiscus sp. Ehrenberg, ER2010-D69, 100 $\mu \mathrm{m}$

2. Spongodiscus sp. Ehrenberg, ER2010-D69, 100 $\mu \mathrm{m}$

3. Undetermined spumellarian, ER2010-D69, 100 $\mu \mathrm{m}$

4. Spongodiscus sp. Ehrenberg, ER2010-E71, 200 $\mu \mathrm{m}$

5. Orbiculiforma (?) sp. Pessagno, ER2010-E76, 200 $\mu \mathrm{m}$

6. Spongodiscus sp. Ehrenberg, ER2010-D69, 100 $\mu \mathrm{m}$

7. Spongodiscus sp. Ehrenberg, ER2010-D69, 100 $\mu \mathrm{m}$

8. Undetermined spumellarian, ER2010-D69, 100 $\mu \mathrm{m}$

9. Spongodiscus sp. Ehrenberg, ER2010-E71, 200 $\mu \mathrm{m}$

10. Spongodiscus sp. Ehrenberg, ER2010-E57, 200 $\mu \mathrm{m}$

11. Orbiculiforma aff. sacramentoensis Pessagno, ER2010-E75, 200 $\mu \mathrm{m}$

12. Orbiculiforma aff. sacramentoensis Pessagno, ER2010-E64, 200 $\mu \mathrm{m}$

13. Patulibracchium aff. teslaensis Pessagno, ER2010-E90, 200 $\mu \mathrm{m}$

14. Patulibracchium (?) sp. Pessagno, ER2010-E90, 200 $\mu \mathrm{m}$

15. Patulibracchium (?) sp. Pessagno, ER2010-E88, 200 $\mu \mathrm{m}$

16. Patulibracchium (?) sp. Pessagno, ER2010-E75, 200 $\mu \mathrm{m}$

17. ?Rhopalosyringium magnificum Campbell\&Clark, ER2010-E88, 100 $\mu \mathrm{m}$

18. ?Rhopalosyringium magnificum Campbell\&Clark, ER2010-E88, 100 $\mu \mathrm{m}$

19. Orbiculiforma (?) sp. Pessagno, ER2010-D69, 200 $\mu \mathrm{m}$

20. ?Stylosphaera sp. $\boldsymbol{c f}$. S. pucilla (Campbell \& Clark), ER2010-D125, 100 $\mu \mathrm{m}$

21. Acaeniotyle (?) sp. Rüst, ER2010-D128, 200 $\mu \mathrm{m}$

22. Archaeocenosphaera (?) sp., ER2010-D125, 200 $\mu \mathrm{m}$

23. Crucella aff. espartoensis Pessagno, ER2010-D125, 200 $\mu \mathrm{m}$

24. Crucella aff. messinae Pessagno, ER2010-E90, 500 $\mu \mathrm{m}$

25. Phaseliforma laxa Pessagno, ER2010-E76, 100 $\mu \mathrm{m}$

26. Phaseliforma laxa Pessagno, ER2010-E57, 100 $\mu \mathrm{m}$

27. Phaseliforma (?) sp. Pessagno, ER2010-E75, 100 $\mu \mathrm{m}$

28. ?Praeconocaryomma sp. Pessagno, ER2010-E64, 100 $\mu \mathrm{m}$

29. ?Praeconocaryomma sp. Pessagno, ER2010-E64, 100 $\mu \mathrm{m}$

30. Praeconocaryomma californiaensis Pessagno, ER2010-E74, 100 $\mu \mathrm{m}$

31. Archaeocenosphaera (?) sp., ER2010-E84, 100 $\mu \mathrm{m}$

32. Archaeocenosphaera (?) sp., ER2010-E74, 100 $\mu \mathrm{m}$

33. Archaeocenosphaera (?) sp., ER2010-E57, 100 $\mu \mathrm{m}$

34. Stylosphaera (?) sp. (Campbell \& Clark), ER2010-E76, 100 $\mu \mathrm{m}$

35. Stylosphaera (?) sp. (Campbell \& Clark), ER2010-E76, 100 $\mu \mathrm{m}$

36. Stylosphaera (?) sp. (Campbell \& Clark), ER2010-E76, 100 $\mu \mathrm{m}$

37. Pyramaspongia (?) sp. Pessagno, ER2010-E74, 100 $\mu \mathrm{m}$

38. ?Orbiculiforma aff. sarcramentoensis Pessagno, ER2010-E64, 100 $\mu \mathrm{m}$

39. Peritiviator labyrinthi (Pessagno), ER2010-E57, 100 $\mu \mathrm{m}$

40. Stylosphaera (?) sp. (Campbell \& Clark), ER2010-E76, 100 $\mu \mathrm{m}$

41. Stylosphaera sp. (Campbell \& Clark), ER2010-E57, 100 $\mu \mathrm{m}$

42. Stylosphaera (?) sp. (Campbell \& Clark), ER2010-E76, 100 $\mu \mathrm{m}$ 

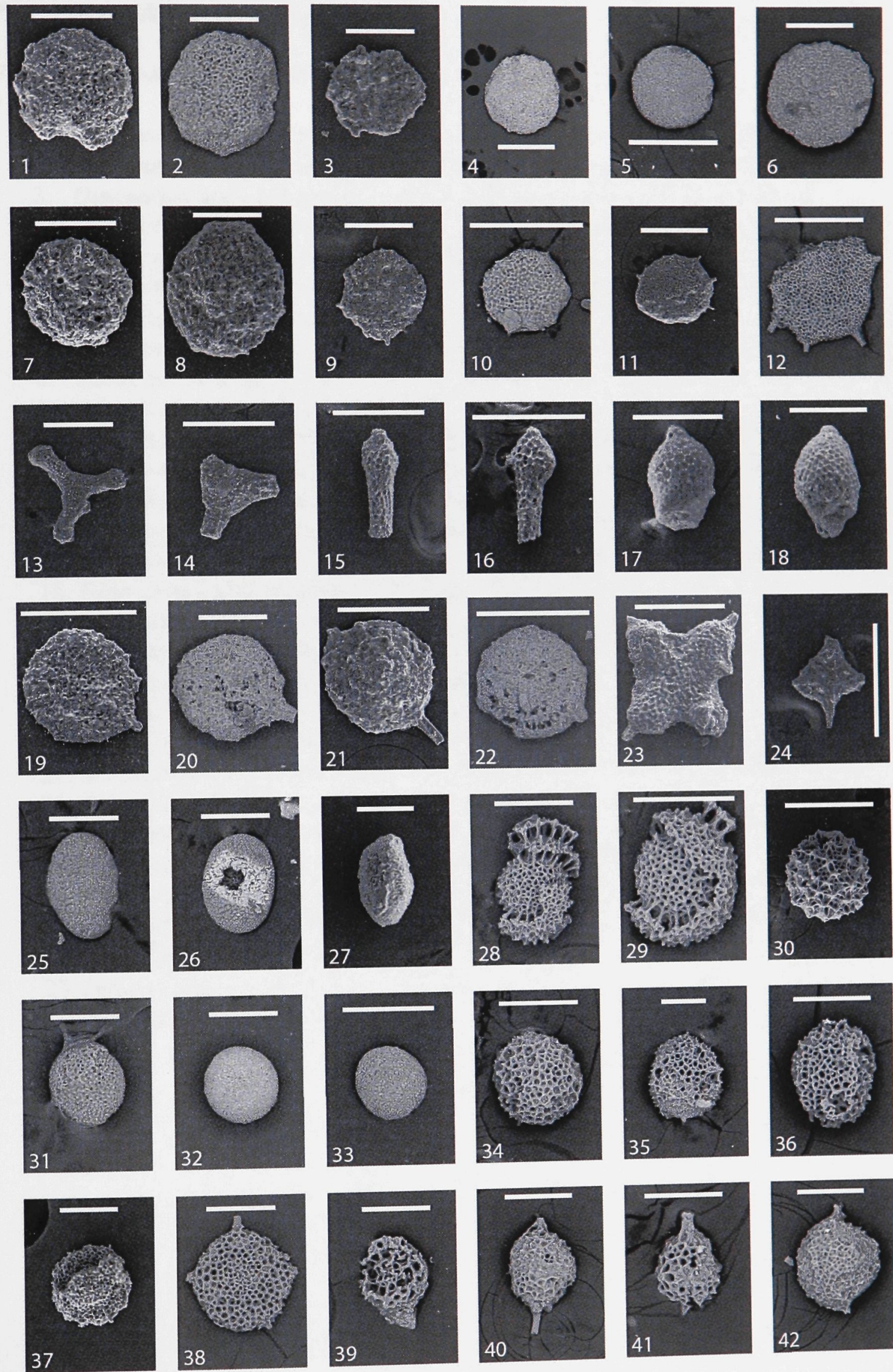
Plate 2: Kanguk Formation Nassellaria

Figure (scale bar length noted beside sample number)

1. Diacanthocapsa aff. granti (Campbell \& Clark), ER2010-E86, 200 $\mu \mathrm{m}$

2. Diacanthocapsa aff. granti (Campbell \& Clark), ER2010-E86, 200 $\mu \mathrm{m}$

3. Diacanthocapsa aff. granti (Campbell \& Clark), ER2010-E90, 200 $\mu \mathrm{m}$

4. Diacanthocapsa granti (Campbell \& Clark), ER2010-E84, 200 $\mu \mathrm{m}$

5. Diacanthocapsa aff. cayeuxi (Squinabol), ER2010-E64, 100 $\mu \mathrm{m}$

6. Diacanthocapsa aff. cayeuxi (Squinabol), ER2010-E64, 100 $\mu \mathrm{m}$

7. Eostichomitra sp. A, ER2010-E87, 200 $\mu \mathrm{m}$

8. Eostichomitra sp. A, ER2010-E62, 100 $\mu \mathrm{m}$

9. Eostichomitra sp. B, ER2010-E60, 100 $\mu \mathrm{m}$

10. Eostichomitra sp. B, ER2010-E60, 100 $\mu \mathrm{m}$

11. Eostichomitra carnegiense (Campbell \& Clark), ER2010-E86, 200 $\mu \mathrm{m}$

12. Eostichomitra carnegiense (Campbell \& Clark), ER2010-E60, 100 $\mu \mathrm{m}$

13. Eostichomitra communis (Squinabol), ER2010-E64, 100 $\mu \mathrm{m}$

14. Eostichomitra communis (Squinabol), ER2010-E62, 100 $\mu \mathrm{m}$

15. Amphiternis aff. stocki (Campbell \& Clark), ER2010-E64, 100 $\mu \mathrm{m}$

16. Dictyomitra multicostata Zittel, ER2010-E60, 200 $\mu \mathrm{m}$

17. Dictyomitra multicostata Zittel, ER2010-E64, 100 $\mu \mathrm{m}$

18. Dictyomitra densicostata Pessagno, ER2010-E64, 200 $\mu \mathrm{m}$

19. Eostichomitra sp., ER2010-E61, 100 $\mu \mathrm{m}$

20. Eostichomitra sp., ER2010-E60, $100 \mu \mathrm{m}$

21. Eostichomitra sp., ER2010-E62, 100 $\mu \mathrm{m}$

22. Schaumellus aff. aufragendus (Empson-Morin), ER2010-E82, $200 \mu \mathrm{m}$

23. Schaumellus (?) sp. A, ER2010-E81, 200 $\mu \mathrm{m}$

24. Schaumellus (?) sp. A, ER2010-E81, 200 $\mu \mathrm{m}$

25. Amphiternis plousios (Foreman), ER2010-E87, 200 $\mu \mathrm{m}$

26. Amphiternis aff. stocki (Campbell \& Clark), ER2010-D125, 200 $\mu \mathrm{m}$

27. Amphiternis aff. stocki (Campbell \& Clark), ER2010-D125, 200 $\mu \mathrm{m}$

28. Xitus spicularis Alieve, ER2010-D125, 200 $\mu \mathrm{m}$

29. Immersothorax (?) sp., ER2010-E75, 200 $\mu \mathrm{m}$

30. Immersothorax (?) sp., ER2010-E75, $200 \mu \mathrm{m}$ 

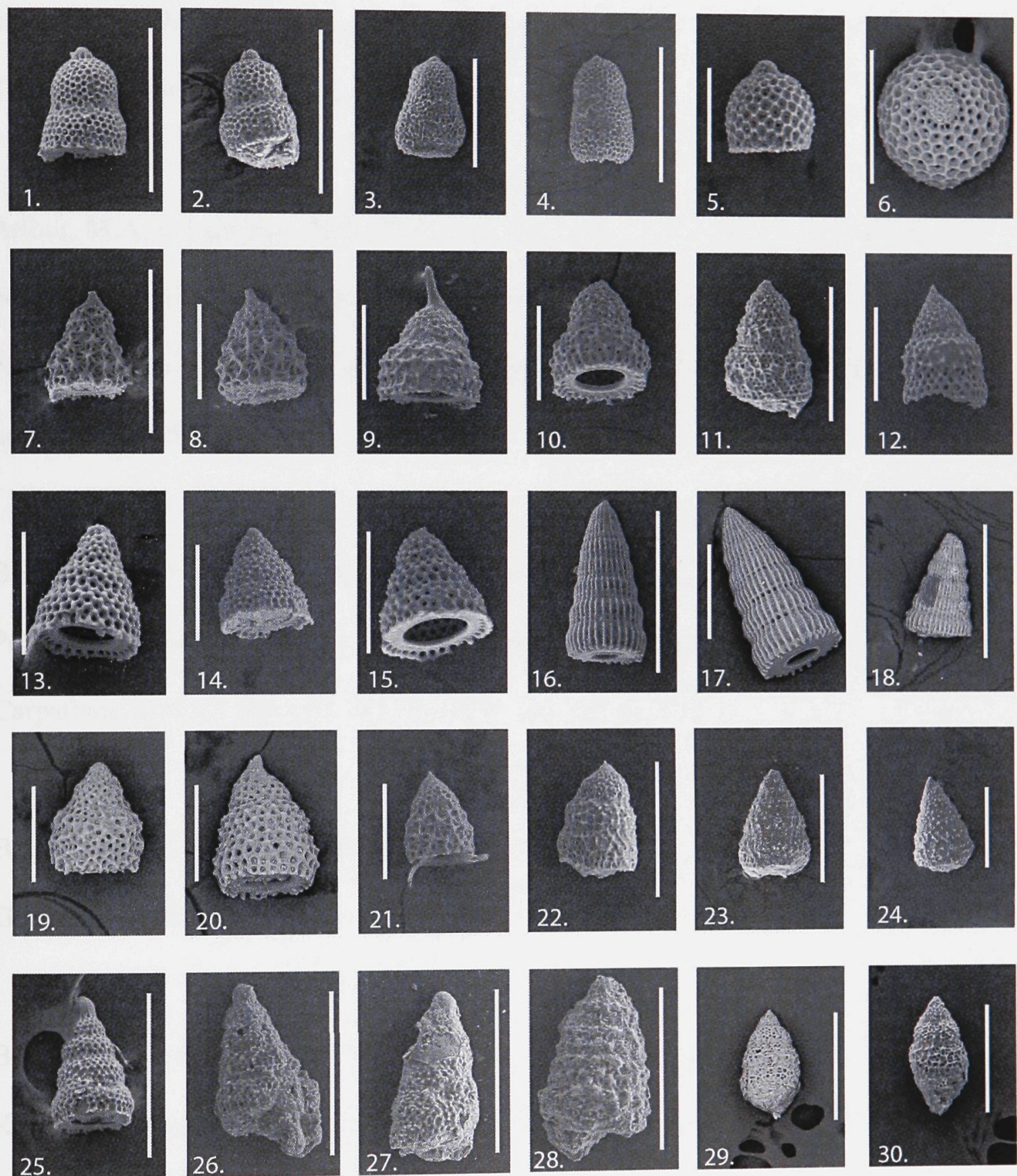


\section{References}

Amon, E.O. \& De Wever, P., 1994. Upper Cretaceous biostratigraphy of the borders of the Ural belt: West Siberia and Eastern Volga-Ural Basins. In: Peri-Tethyan platforms. Technip Edition, Paris, pp. 229-262.

Arthur, M.A. \& Sageman, B.B., 2005. Sea-level control on source-rock development: perspectives from the Holocene Black Sea, the mid-Cretaceous Western Interior Basin of North America, and the Late Devonian Appalachian Basin. SEPM Special Publication no. 82 , pp. $35-59$.

Bak, M., 1999. Cretaceous radiolaria from the Pieniny Succession, Pieniny klippen Belt, Polish Carpathians. Geology of the Pieniny Klippen Belt and the Tatra Mountains, Carpatians. Studia Geologica Polonica, vol. 115, pp. 91-115.

Balkwill, H.R., 1978. Evolution of Sverdrup Basin. American Association of Petroleum Geologists Bulletin, vol. 62, pp. 1004-1028.

Bandini, A.N., Baumgartner, P.O., \& Caron, M., 2006. Turonian Radiolarians from Karnezeika, Argolis Peninsula, Peloponnesus (Greece), Eclogae geol. Helv. vol. 99, Supplement 1, SI-S20. 
Barron, E.J., 1983. A warm, equable Cretaceous: The nature of the problem. Earth-

Science Reviews, vol. 19, pp. 305-338.

Bartolini, A., Baumgartner, P.O., \& Guex, J., 1999. Middle and Late Jurassic radiolarian palaeoecology versus carbon-isotope stratigraphy. Palaeogeography, Palaeoclimatology, Palaeoecology, vol.145, pp. 43-60.

Baumgartner, P.O., 1992. Lower Cretaceous radiolarian biostratigraphy and biogeography of northwestern Australia (ODP Sites 765 and 766 and DSDP Site 261), Argo Abyssal Plain and Lower Exmouth Plateau. Proc. ODP, Sci. Results 123, pp. 299342.

Baumgartner, P.O., Liechti, R., \& O'Dogherty, L., 2012. InterRad-Mesozoic Radiolarian Database. Retrieved from http://www2.unil.ch/interrad-mrd/login.php?dbase=radiolaria

Berkeley, A., Perry, C.T., Smithers, S.G., Horton, B.P., \& Taylor, K.G., 2007. A review of the ecological and taphonomic controls on foraminiferal assemblage development in intertidal environments. Earth-Science Reviews, vol. 83, pp. 205-230.

Bertrand, P., Lallier-Verges, E., \& Boussafir, M., 1994. Enhancement of accumulation and anoxic degradation of organic matter controlled by cyclic productivity: a model. Organic geochemistry, vol. 22, no.3, pp. 511-520. 
Blakey, R., 2012. Paleogeography Library. Retrieved from

http://cpgeosystems.com/globaltext2.html

Boutelier, J., Cruden, A., Brent, T., \& Stephenson, R., 2010. Timing and mechanisms controlling evaporite diapirism on Ellef Ringnes Island, Canadian Arctic Archipelago. Basin Research, vol.23, pp. 478-498.

Bragina, L.G., 1994. Radiolaria and stratigraphy of the Upper Cretaceous deposits of Khotkovian Seria of Moscow Region. Bulletain Moskovskogo Obshestva Ispitatelei Prirodi, Geologicheskoe Otdelenie, Moscow, vol. 69, no. 2, pp. 91-100.

Campbell, A.S. and Clark, B.L., 1944. Radiolaria from Upper Cretaceous of Middle California. Geological Society of America, Special Paper, no. 57, pp. 1-61.

Catuneanu, O., 2002. Sequence stratigraphy of clastic systems: concepts, merits, and pitfalls. Journal of African Earth Sciences, vol. 35, pp. 1-43.

Chin, K., Bloch, J., Sweet, A., Tweet, J., Eberle, J., Cumbaa, S., Witkowski, J. \& Harwood, D., 2008. Life in a temperate Polar sea: a unique taphonomic window on the structure of a Late Cretaceous Arctic marine ecosystem. Proceedings of the Royal Society B: Biological Sciences, vol. 275, pp. 2675-2685. 
Clifton, H. E., Hunter, R. E., \& Phillips, R. L., 1971. Depositional structures and processes in the non-barred high-energy nearshore. Journal of Sedimentary Research, vol. 41, no. 3, pp. 651-670.

De Wever, P., Dumitrica, P., Caulet, J.P., Nigrini, C., \& Caridroit, M., 2001, Radiolarians in the Sedimentary Record. Gordon and Breach Science Publishers, Amsterdam, 533 pp.

Embry, A.F., 1990, A tectonic origin for third-order depositional sequences in extensional basins implications for basin modeling, In: Cross, T. (ed.), Quantitative dynamic stratigraphy, Prentice Hall, Engelwood Cliffs, USA, pp. 491-502.

Embry, A.F., 1991, Mesozoic history of the Arctic Islands, In: Trettin, H.P. (ed.), Geology of the Innuitian Orogen and Arctic platform of Canada and Greenland, Geological Survey of Canada, Ottawa, Canada, pp. 369-433.

Embry, A.F., 2009, Crockerland - The Source Area for the Triassic to Middle Jurassic Strata of Northern Axel Heiberg Island, Canadian Arctic Islands. Bulletin of Canadian Petroleum Geology, vol. 57, no. 2, pp 129-140.

Embry, A.F., \& Beauchamp, B., 2008. Sverdrup Basin, In: Miall, A.D., (ed.), Sedimentary Basins of the World, vol. 5, Elsevier Science Limited, pp. 451-471. 
Embry, A.F., \& Dixon, J., 1990. The breakup unconformity of the Amerasia Basin, Arctic Ocean: Evidence from Arctic Canada. Geological Society of America Bulletin, vol. 102, pp. 1526-1534.

Embry, A.F., \& Osadetz, K., 1988. Stratigraphy and tectonic significance of Cretaceous volcanism, Queen Elizabeth Islands, Arctic Archipelago. Canadian Journal of Earth Sciences, vol. 25, pp. 1209-1219.

Empson-Morin, K.M., 1981. Campanian Radiolaria from DSDP site 313, Mid-Pacific Mountains. Micropaleontology, vol. 27, no.3,pp. 249-292

Empson-Morin, K.M., 1984. Depth and latitude distribution of Radiolaria in Campanian (Late Cretaceous) tropical and subtropical oceans. Micropaleontology, vol. 30, no. 1, pp. 87-115.

Erbacher, J., 1995. 29. Mid-Cretaceous radiolarians from the eastern equatorial Atlantic and their paleoceanogrpahy. In: Proceedings of the Ocean Drilling Program: Scientific results, v. 159, pp. 363-373.

Erbacher, J., \& Thurow, J., 1988. Mid-Cretaceous radiolarian zonation for the North Atlantic: an example of oceanographically controlled evolutionary processes in the marine biosphere? In: Cramp, A., Macleod, C. J., Lee, S. V. \& Jones, E. J. W. (eds) 
Geological Evolution of Ocean Basins: Results from the Ocean Drilling Program.

Geological Society, London, Special Publications, vol. 131, pp. 71-82.

Erbacher, J., Thurow, J., \& Littke, R., 1996. Evolution patterns of Radiolaria and organic matter variations: a new approach to identify sea-level changes in mid-Cretaceous pelagic environments. Geology, vol. 24, no. 6, pp. 499-502.

Espitalie, J., Laporte, L.J., Madec, M., Marquis, F., Leplat, P., Paulet, J., \& Boutefeu, A., 1977. Methode rapide de caracterisation des roches mères, de leur potential petrolier et de leur degree d'evolution. Rev.,Inst.Franc.Pétrole, vol. 32, pp. 32-42.

Filatova, N.I., \& Vishnevskaya, V.S., 1997. Radiolarian stratigraphy and origin of the Mesozoic terranes of the continental framework of the northwestern Pacific (Russia). Tectonophysics, vol. 269, pp. 131-150.

Foreman, H.P., 1975. Radiolaria from the North Pacific, Deep Sea Drilling Project, Leg 32. In: Larson, R. L., Moberly, R., et al. (eds.) Initial Reports of the Deep Sea Drilling Project, vol. 32. Washington, D.C.,U.S. Government Printing Office. pp. 579-676

Friedrich, O., Norris, R. D., \& Erbacher, J., 2012. Evolution of middle to Late Cretaceous oceans-A 55 my record of Earth's temperature and carbon cycle. Geology, vol. 40, no. 2, pp.107-110. 
Galloway, J. M., Sweet, A. R., Pugh, A., Schröder-Adams, C. J., Swindles, G. T., Haggart, J. W., \& Embry, A. F., 2012. Correlating middle Cretaceous palynological records from the Canadian High Arctic based on sections from the Sverdrup Basin and the Eclipse Trough. Palynology, DOI:10.1080/01916122.2012.670411.

Gebhardt, H., Friedrich, O., Schenk, B., Fox, L., Hart, M., \& Wagreich, M., 2010, Paleoceanographic changes at the northern Tethyan margin during the CenomanianTuronian Oceanic Anoxic Event (OAE-2). Marine Micropaleontology, vol. 77, pp. 25-45.

Gould, D.B. \& Demille, G., 1964. Piercement structures in the Arctic Islands. Bulletin of Canadian Petroleum Geology, vol. 12, pp. 719-753.

Haggart, J.W., 2011. Report on Late Cretaceous fossils from Ellef Ringnes Island, Canadian Arctic Archipelago (NTS 069E). Geological Survey of Canada, Paleontological Report JWH-2011-07, 2 p.

Heywood, W.W., 1955. Arctic piercement domes. Canadian Institute of Mining and Metallurgy Bulletin, vol. 48. p. 59-64.

Heywood, W.W., 1957. Ellef Ringnes Island, District of Franklin, Northwest Territories. Geological Survey of Canada, Paper 56-8, 36 p. 
Hollis, C. J., \& Kimura, K., 2001. A unified radiolarian zonation for the Late Cretaceous and Paleocene of Japan. Micropaleontology, vol. 47, no. 3, pp. 235-255.

Hopkins, W.S. Jr., \& Balkwill, H.R., 1973. Description, Palynology and Paleoecology of the Hassel Formation (Cretaceous) on Eastern Ellef Ringnes Island, District of Franklin. Geological Survey of Canada, Paper 72-37, pp. 1-31.

Huber, B.T., Norris, R.D., \& MacLeod, K.G., 2002. Deep-sea paleotemperature record of extreme warmth during the Cretaceous. Geology, vol. 30, pp. 123-126.

Jeletzky, J.A., 1968. Macrofossil zones of the marine Cretaceous of the Western Interior of Canada and their correlation with the zones and stages of Europe and the Western Interior of the United States. Geological Survey of Canada, Paper 67-72, pp. 1-66.

Jeletzky, J.A., 1970. Cretaceous macrofaunas. In: Geology and Economic Minerals of Canada. (EG 1, 5th Edition). Geological Survey of Canada, pp. 649-662.

Kominz, M.A., Browning, J.V., Miller, K.G., Sugarman, P.J., Misintseva, S., \& Scotese, C.R., 2008. Late Cretaceous to Miocene sea-level estimates from the New Jersey and Delaware coastal plain coreholes: an error analysis. Basin Research, vol. 20, pp. 211-226. 
Leckie, D. A., Singh, C., Bloch, J., Wilson, M., \& Wall, J., 1992. An anoxic event at the Albian-Cenomanian boundary: the Fish Scale marker bed, northern Alberta, Canada. Palaeogeography, Palaeoclimatology, Palaeoecology, vol. 92, no. 1, pp. 139-166.

Leckie, R.M., Bralower, T.J., \& Cashman, R., 2002. Oceanic anoxic events and plankton evolution: Biotic response to tectonic forcing during the mid-Cretaceous.

Paleoceanography, vol. 17, no. 3 , pp. 1-29.

Musavu-Moussavou, B., \& Danelian, T., 2006. The Radiolarian biotic response to Oceanic Anoxic Event 2 in the southern part of the Northern proto-Atlantic (Demerara Rise, ODP Leg 207). Revue de Micropaleontologie, vol. 49, no. 3, pp. 141-163.

Núñez-Betelu, L. K., Hills, L. V., \& MacRae, R. A., 1994. Palynostratigraphy and hydrocarbon potential of the Upper Cretaceous Kanguk Formation: an integrated multidisciplinary analysis of the northeastern Canadian Arctic Archipelago. In: Proceedings of the international conference on Arctic margins, pp. 54-61.

O’Dogherty, L., De Wever, P., Goričan, Š., Carter, E. S., \& Dumitrica, P., 2011.

Stratigraphic ranges of Mesozoic radiolarian families. Palaeoworld, vol. 20, no. 2, pp. $102-115$. 
Odin, G. S. (Ed.), 1988. Green Marine Clays: Oolitic Ironstone Facies, Verdine Facies, Glaucony Facies, and Celadonite-bearing Facies: a Comparative Study. Developments in Sedimentology, vol. 45, Elsevier Science Limited.

ODSN, 2012. ODSN Plate Tectonic Reconstruction Service. Retrieved from http://www.odsn.de/odsn/services/paleomap/paleomap.html

Pemberton, S. G., Spila, M., Pulham, A. J., Saunders, T., MacEachern, J. A., Robbins, D., \& Sinclair, I. K., 2001. Ichnology and sedimentology of shallow to marginal marine systems: Ben Nevis \& Avalon Reservoirs, Jeanne d'Arc Basin. Short Course Notes 15. Geological Association of Canada, St. John's, Newfoundland, 343 p.

Pessagno, E.A. Jr., 1976. Radiolarian zonation and stratigraphy of the Upper Cretaceous portion of the Great Valley Sequence, California Coast Ranges. Micropaleontology, Special Publication no. 2, 95 pp.

Pessagno, E.A. Jr., 1977. Lower Cretaceous Radiolarian Biostratigraphy of the Great Valley Sequence and Franciscan Complex, California Coast Ranges. Cushman Foundation for Foraminiferal Research, Special Publication no. 15, pp. 5-87.

Popova-Goll, I., Vishnevskaya, V., \& Baumgartner, P. O., 2005. Upper Cretaceous (Santonian-Campanian) radiolarians from Voronesh Anticline, southwestern Russia. Micropaleontology, vol. 51, no. 1, pp. 1-37. 
Price, G. D., 1999. The evidence and implications of polar ice during the Mesozoic. Earth-Science Reviews, vol. 48, no. 3, pp.183-210.

Sageman, B. B., Murphy, A. E., Werne, J. P., Ver Straeten, C. A., Hollander, D. J., \& Lyons, T. W., 2003. A tale of shales: the relative roles of production, decomposition, and dilution in the accumulation of organic-rich strata, Middle-Upper Devonian, Appalachian basin. Chemical Geology, vol. 195, no.1, pp.229-273.

Schröder-Adams, C.J., Herrle, J.O., \& Tu, Q., 2012. Albian to Santonian carbon isotope excursions and faunal extinctions in the Canadian Western Interior Sea: Recognition of eustatic sea-level controls on a forebulge setting. Sedimentary Geology, v. 281, pp. 5058.

Scotese, C.R., 2002. Earth History. Retrieved from http://scotese.com/earth.htm.

Scott, C., \& Lyons, T. W., 2012. Contrasting molybdenum cycling and isotopic properties in euxinic versus non-euxinic sediments and sedimentary rocks: Refining the paleoproxies. Chemical Geology, doi:10.1016/j.chemgeo.2012.05.012

Shanmugam, G., 2006. Deep-water processes and facies models: Implications for sandstone petroleum reservoirs (Vol. 5). Elsevier Science, Amsterdam. 
Sliter, W.V., 1981. Albian foraminifers from the lower Cretaceous Christopher

Formation of the Canadian Arctic Islands. Geological Survey of Canada Bulletin, vol. 300 , pp. $41-70$.

Stott, D.F., 1969. Ellef Ringnes Island, Canadian Arctic Archipelago. Geological Survey of Canada, Paper 68-16. 30 p.

Stow, D. A. V., Huc, A. Y., \& Bertrand, P., 2001. Depositional processes of black shales in deep water. Marine and Petroleum Geology, vol. 18, no. 4, pp. 491-498.

Tapia, P. M., and D. M. Harwood, 2002. Upper Cretaceous diatom biostratigraphy of the Arctic Archipelago and northern continental margin, Canada. Micropaleontology, vol. 48, pp. 303-342.

Tappan, H., 1960. Cretaceous Biostratigraphy of Northern Alaska. American Association of Petroleum Geologists Bulletin, vol. 44, no. 3, pp. 273-297.

Tappan, H., 1962. Foraminifera from the Arctic Slope of Alaska. Geological Survey Professional Paper, vol. 236-C, pp. 91-209, plates 229-258.

Then, D.R. \& Dougherty, B.J., 1983. A new procedure for extracting foraminifera from indurated organic shale, In: Current Research, Part B, Geological Survey of Canada, Paper 83-1B, pp. 413-414. 
Thomson, D., Schröder-Adams, C.J., Hadlari, T., Dix, G., \& Davis, W.J., 2011. Albian to Turonian stratigraphy and palaeoenvironmental history of the northern Western Interior Sea in the Peel Plateau Region, Northwest Territories, Canada. Palaeogeography, Palaeoclimatology, Palaeoecology, vol. 302, no. 3-4, pp. 270-300

Thorsteinsson, R., 1974. Carboniferous and Permian stratigraphy of Axel Heiberg Island and western Ellesmere Island, Canadian Arctic Archipelago. Geological Survey of Canada Bulletin, vol. 224, 86 pp.

Thorsteinsson, R., \& Tozer, E.T. 1970. Geology of the Arctic Archipelago. In: Douglas, R.J. W. editor. Geology and Economic Minerals of Canada. Geological Survey of Canada, Economic Geology Report No. 1.pp. 548-590.

Thurow, J., 1988. Cretaceous radiolarians of the North Atlantic Ocean: ODP Leg 103 (Sites 638, 640, and 641) and DSDP Legs 93 (Site 603) and 47B (Site 398). In: Boillot, G., Winterer, E.L., et al. (eds.), Proc. ODP, Sci. Results, vol. 103, pp. 379-418.

Torsvik, T. H., Carlos, D., Mosar, M., Cocks, L. R. M. \& Malme, T., 2002. Global reconstructions and North Atlantic paleogeography 440 Ma to Recent. In: Eide, E. A. (ed.) BATLAS - Mid Norway Plate Reconstruction Atlas with Global and Atlantic Perspectives. Geological Survey of Norway, Trondheim, pp.18-39. 
Trettin, H.P. (ed.) 1991: Geology of the Innuitian Orogen and Arctic Platform of Canada and Greenland. Geology of Canada no. 3, 569 pp. + map vol. Ottawa: Geological Survey of Canada

Trettin, H.P., \& Parrish, R. 1987. Late Cretaceous bimodal magmatism, northern Ellesmere Island: isotopic age and origin. Canadian Journal of Earth Sciences, vol. 24, pp. 257-265.

Turgeon, S., \& Brumsack, H. J., 2006. Anoxic vs. dysoxic events reflected in sediment geochemistry during the Cenomanian-Turonian Boundary Event (Cretaceous) in the Umbria-Marche Basin of central Italy. Chemical Geology, vol. 234, no. 3, pp. 321-339.

Ver Straeten, C. A., Brett, C. E., \& Sageman, B. B., 2011. Mudrock sequence stratigraphy: A multi-proxy (sedimentological, paleobiological and geochemical) approach, Devonian Appalachian Basin. Palaeogeography, Palaeoclimatology, Palaeoecology, vol. 304, no. 1, pp. 54-73.

Vishnevskaya, V.S., 1986. Middle to Late Cretaceous radiolarian zonation of the Bering region, USSR. Marine Micropaleontology, vol. 11, no. 1, pp.139-149.

Vishnevskaya, V.S.,1997. Development of Palaeozoic-Mesozoic Radiolaria in the Northwestern Pacific Rim. Marine Micropaleontology, vol. 30, pp. 79-95. 
Vishnevskaya, V.S., \& De Wever, P., 1998. Upper Cretaceous Radiolaria from the Russian Platform (Moscow Basin). Revue de Micropaleontologie, vol. 41, no. 3, pp.235265.

Vishnevskaya, V. S., De Wever P., Baraboshkin E. Vu. et al., 1999. New stratigraphic and palaeogeographic data on Upper Jurassic to Cretaceous deposits from the eastern periphery of the Russian Platform (Russia). Geodiversitas, vol. 21, no. 3, pp. 347-363.

Wall, J.H., 1975. Diatoms and radiolarians from the Cretaceous system of Alberta, a preliminary report. In: The Cretaceous System in the Western Interior of North America. Geological Association of Canada Special Paper, no. 13, pp. 391-410.

Wall, J.H., 1983. Jurassic and Cretaceous foraminiferal Biostratigraphy in the eastern Sverdrup Basin, Canadian arctic archipelago. Bulletin of Canadian Petroleum Geology, v. 31, no. 4, pp. 246-281.

Wynne, P.J., Irving, R., \& Osadetz, K., 1988. Paleomagnetism of Cretaceous volcanic rocks of the Sverdrup Basin - magnetostratigraphy, paleolatitudes, and rotations. Canadian Journal of Earth Sciences, vol. 25, pp. 1220-1239.

Young, G. M., \& Nesbitt, H. W., 1998. Processes controlling the distribution of Ti and Al in weathering profiles, siliciclastic sediments and sedimentary rocks. Journal of Sedimentary Research, vol. 68, no. 3, pp. 448-455. 
Ziegler, A.M., \& Rowley, D.B., 1998. The vanishing record of epeiric seas, with emphasis on the Late Cretaceous "Hudson Seaway". In: Crowley, T.J., Burke, T.J. (eds.), Tectonic Boundary Conditions for Climate Reconstructions. Oxford Monographs on Geology and Geophysics. Oxford University Press, pp. 147-165. 